\section{Effect of nickel on the hydrogen stress cracking resistance of ferritic/pearlitic low alloy steels}

\author{
Hans Husby, * Philip Wagstaff, * Mariano Iannuzzi, \\ *** Roy Johnsen, * and Mariano Kappes. ***
}

\section{ARTICLE INFO}

Article history:

Received Day Month Year Accepted Day Month Year Available Day Month Year

Keywords:
A. Oil \& gas
B. Low alloy steels
C. Nickel
D. Hydrogen embrittlement
E. Slow strain rate test

\author{
* Department of Mechanical and Industrial Engineering, Norwegian University \\ of Science and Technology, 7491 Trondheim, Norway. \\ ** GE Oil \& Gas and NTNU, 1338 Sandvika, Norway, currently at Curtin \\ University, Bentley, Australia. \\ *** Instituto Sabato, San Martín, Argentina. \\ ‡ Corresponding author: +4790183360. \\ Email: hans.husby@ntnu.no.
}

\begin{abstract}
Nickel additions to low alloy steels improve mechanical and technological properties. However, part 2 of the ISO 15156 Standard limits the nickel content to a maximum of $1 \mathrm{wt} \%$ in oil and gas environments containing $\mathrm{H}_{2} \mathrm{~S}$ due to controversial concerns regarding sulfide stress cracking. The objective of this work was to investigate the effect of nickel in solid solution in the ferrite phase on hydrogen stress cracking resistance. Ferritic/pearlitic research-grade low alloy steels with nominal nickel contents of $0,1,2$ and 3 wt\% were tested by the slow strain rate test method with cathodic hydrogen charging to -1.05 and $-2 \mathrm{~V}_{\mathrm{Ag} / \mathrm{AgCl}}$. No difference in fracture mode or morphology was found between the alloys. However, the plastic elongation ratios and reduction in area ratios decreased with increasing nickel content when tested at $-2 \mathrm{~V}_{\mathrm{Ag} / \mathrm{AgCl}}$. The direct and indirect effects of nickel, such as the influence of an increasing fraction of pearlite with increasing nickel content, are discussed.
\end{abstract}

\section{INTRODUCTION}

Due to the ever-increasing energy demand, conventional oil and gas reserves are becoming increasingly scarce. ${ }^{1} \mathrm{New}$ oil and gas fields often include severe temperature and pressure conditions combined with the potential for reservoir souring, i.e., the production of hydrogen sulfide. ${ }^{2}$ Likewise, an increasing number of reservoirs can be
Harsh environments invoke strict material requirements. In this regard, researchers argue that, in the next 10 to 15 years, there will be an increased demand for low alloy steels (LAS) with a unique combination of mechanical, corrosion, and technological properties. For example, LAS with (i) homogeneous through-thickness yield strength (YS) levels above $690 \mathrm{MPa}$, (ii) ductile to brittle transition temperatures (DBTT) below $-60^{\circ} \mathrm{C}$, and (iii) adequate sour service resistance could become the norm in high-pressure, high-temperature (HPHT) and arctic equipment. ${ }^{4,5}$

LAS are widely used in oil and gas production due to their excellent mechanical properties and low cost. ${ }^{4}$ Mechanical properties are improved by alloying. LAS often contain manganese, chromium, molybdenum, and nickel. $\mathrm{Ni}$, an element that does not form carbides and has a solubility in the bcc ferrite structure of about $7 \mathrm{wt} \%, 4,6$ increases strength and toughness simultaneously, while lowering DBTT, increasing hardenability, and imparting the lowest penalty on weldability. ${ }^{4}$

The use of LAS in environments containing $\mathrm{H}_{2} \mathrm{~S}$ is governed by Part 2 of the ISO 15156 Standard, ${ }^{7}$ which restricts the Ni content to a maximum of 1 wt\% for use in any $\mathrm{H}_{2} \mathrm{~S}$ condition due to concerns regarding sulfide stress cracking (SSC) resistance, as stated in Annex A of the standard. At present, carbon and low alloy steels exceeding the $1 \mathrm{wt} \% \mathrm{Ni}$ restriction require complicated and expensive qualification testing, which often implies a de facto ban in allowable Ni content. ${ }^{3}$

SSC is a form of hydrogen stress cracking (HSC) that results from the combined presence of atomic hydrogen in the metal and tensile stresses in an $\mathrm{H}_{2} \mathrm{~S}$ environment. ${ }^{8}$ One of the first reports suggesting a negative effect of $\mathrm{Ni}$ on SSC resistance was presented by Treseder and Swanson ${ }^{9}$ in 1967. The authors performed 3-point bend testing on AISI 4140 (UNS G41400) steel with $<0.25$ wt $\% \mathrm{Ni}$ and the corresponding AISI 4340 (UNS G43400) steel with 1.65 to $2.0 \mathrm{wt} \% \mathrm{Ni}$, tempered to varying hardness levels. They observed an apparent adverse effect of $\mathrm{Ni}$ for comparable hardness levels. The conclusions from Treseder and Swanson were immediately questioned by Snape ${ }^{10}$ who argued that the critical transformation temperature had been exceeded during tempering of the steels containing $>1 \mathrm{wt} \% \mathrm{Ni}$. In this regard, exceeding the critical transformation temperature causes the formation of untempered martensite upon cooling, which is known to be detrimental to SSC resistance. ${ }^{4}$ Overlapping effects from varying chemical compositions and changing microstructures have also obscured the intrinsic effect of $\mathrm{Ni}$ in several subsequent works as discussed by Kappes et al. ${ }^{4}$ The effect of $\mathrm{Ni}$ on SSC resistance was extensively investigated in the 1980's. ${ }^{9}, 11-19$ Although most researchers suggested that $\mathrm{Ni}$ did not play a direct role in sour service performance, the engineering community has yet to reach consensus as to whether the cap on nickel was scientifically justified. ${ }^{4}$

LAS containing $\mathrm{Ni}, \mathrm{Mo}$, and $\mathrm{Cr}$ for use in oil and gas production equipment are normally heat treated to exhibit fully tempered martensitic or lower bainitic microstructures. ${ }^{4}$ Consequently, most research on the effect of $\mathrm{Ni}$ on SSC resistance has been conducted on quenched and tempered (QT) LAS. While evaluating QT microstructures gives relevant information about service performance, separating the effect of nickel from that of other metallurgical variables is extremely difficult. Therefore, the objective of this investigation was to determine the effect of $\mathrm{Ni}$ as a solid solution alloying element in the ferrite phase on HSC resistance. Researchgrade LAS with nominal Ni contents of $0,1,2$ and $3 \mathrm{wt} \%$ were heat treated to ferritic/pearlitic microstructures and the effect of hydrogen 
was compared using slow strain rate testing (SSRT) in a $3.5 \mathrm{wt} \% \mathrm{NaCl}$ electrolyte with cathodic hydrogen charging. The SSRT method was chosen by means of its rapid and efficient ability to screen materials with respect to their HSC susceptibility. ${ }^{20}$

\section{EXPERIMENTAL}

\section{Materials}

Four research-grade LAS with nominal Ni contents of $0,1,2$, and $3 \mathrm{wt} \%$ were manufactured for this investigation. The actual chemical composition of the LAS is given in Table 1. The alloys were vacuum induction melted at $1600^{\circ} \mathrm{C}$ and fully "killed" (i.e., deoxidized) and finegrain treated by aluminum addition. Calcium was added for inclusion shape control. The level of impurities was analyzed using glow discharge mass spectroscopy. The Watanabe $(J)$ and Bruscato $(X)$ factors ${ }^{21}$ were calculated to evaluate the cleanliness of the LAS and to infer their susceptibility to temper embrittlement. As seen in Table 1, the maximum values were 9.1 and 0.6 , respectively, confirming a LAS with an extremely low level of impurities that could be considered, $a$ priori, immune to temper embrittlement. ${ }^{22}$

\section{Heat treatment and characterization}

Details of the heat treatment procedure are given elsewhere. ${ }^{23}$ In short, the materials were cast and hot-rolled, and delivered as plates with thicknesses of approximately $10 \mathrm{~mm}$. The as received materials had banded microstructures and were homogenized by heating at $1200^{\circ} \mathrm{C}$ for 7 days. It was considered important to remove banding since it may have a direct effect on SSC resistance ${ }^{24}$ and Ni steels are prone to banding. ${ }^{25}$ After homogenization, the samples were heated above the upper and below the lower austenite transformation temperatures multiple times to obtain similar ferritic/pearlitic microstructures for all Ni contents.

Microstructures of the tested SSRT samples were analyzed in the scanning electron microscope (SEM) after testing for each Ni content. Surface preparation to reveal the microstructures consisted of grinding using SiC paper up to U.S. grit 600 (European P1200) followed by polishing to $1 \mu \mathrm{m}$ diamond suspension and finally electropolishing. Electropolishing was done in a commercially available electropolishing equipment. The electrolyte was a commercial product based on perchloric acid, ethanol, and 2-Butoxyethanol that is suited for carbon and low alloy steels. The samples were electropolished for $30 \mathrm{~s}$ at $40 \mathrm{~V}$.

Grain size, pearlite content, and interlamellar pearlite spacing of the alloys were characterized on a separate set of samples, which were heat treated identically to the SSRT samples as described elsewhere. ${ }^{23}$ The results are repeated in the results section since they are important for the discussion of the SSRT results.

\section{Polarization curves}

Polarization curves were performed on homogenized samples of 0 and $3 \mathrm{wt} \% \mathrm{Ni}$. The polarization curves were carried out in a standard threeelectrode setup with a platinum counter electrode (CE) and a silversilver chloride reference electrode $(\mathrm{Ag} / \mathrm{AgCl}$ in saturated $\mathrm{KCl})$ with potentials of $-0.04 \mathrm{~V}$ vs. the saturated Calomel electrode (SCE) and $+0.20 \mathrm{~V}$ vs. the standard hydrogen electrode (SHE) at $25^{\circ} \mathrm{C} .{ }^{26}$ The electrolyte was deaerated $3.5 \mathrm{wt} \% \mathrm{NaCl}$ solution, $\mathrm{pH}=5.4-$ measured in aerated conditions - with a total volume of $700 \mathrm{ml}$. Tests were conducted at room temperature $\left(24 \pm 1^{\circ} \mathrm{C}\right)$. The samples were disks with a diameter of about $29 \mathrm{~mm}$ and a thickness of about $1.3 \mathrm{~mm}$. The exposed sample area in the solution was approximately $13 \mathrm{~cm}^{2}$.
The sample surfaces were ground using $\mathrm{SiC}$ abrasive paper down to U.S. grit 600 (European P1200). Specimens were rinsed in cold tap water and distilled water, in that order, sonicated in ethanol for $60 \mathrm{~s}$ and subsequently dried with warm air. A wire for electrical connection was spot-welded to the sample side. The wire connection point was coated with an epoxy paint, which cured overnight - inside a desiccator at room temperature - before the experiment started. Samples were suspended vertically from the wire inside the cell with all sides freely exposed to the electrolyte.

The 3.5 wt $\% \mathrm{NaCl}$ solution was deaerated for 20 minutes before immersion of the sample. Deaeration continued in the cell by purging with nitrogen gas both before and during the polarization experiments. The open circuit potential (OCP) was measured for $1 \mathrm{~h}$ before polarization. The polarization curves were recorded from -1350 $\mathrm{mV}_{\mathrm{Ag} / \mathrm{AgCl}}$ to $-400 \mathrm{mV}_{\mathrm{Ag} / \mathrm{AgCl}}$ using a scan rate of $0.17 \mathrm{mV} \mathrm{s}^{-1}(10.2 \mathrm{mV}$ $\left.\min ^{-1}\right) \cdot{ }^{27}$

\section{Slow strain rate testing}

The as-received plates were cut into bars aligned parallel to the longtransverse (LT) direction before heat treatment. The bars were heat treated, and subsequently machined in a lathe with final dimensions as shown in Figure 1. The gauge section had a length of $25.4 \mathrm{~mm}$ and a diameter of $3.81 \mathrm{~mm}$. The sample dimensions were in accordance with the NACE TM0198 standard ${ }^{28}$ with the modification that the cross section diameter outside the gage section was $11 \mathrm{~mm}$ instead of the recommended $6.35 \mathrm{~mm}$. The sample dimensions are also found in the NACE TM0177 standard ${ }^{29}$ as a combination of the requirements for standard and sub-size tensile test samples. The gauge section was ground with abrasive U.S. grit 600 (European P1200) SiC paper, by hand, in the direction parallel to the length of the sample just before the experiment. Corresponding grinding/polishing of the gauge section has been reported for similar testing. ${ }^{11,30,31}$ Samples were rinsed in cold tap water, then distilled water, and finally sonicated in ethanol for about $60 \mathrm{~s}$. Lastly, the sample was dried with warm air.

The SSRT experiments were performed at room temperature, measured to $24 \pm 1^{\circ} \mathrm{C}$. The electrolyte was a $3.5 \mathrm{wt} \% \mathrm{NaCl}$ solution with an as prepared $\mathrm{pH}$ of 5.4 in aerated conditions. The samples were immersed in the electrolyte and charged with hydrogen during straining.

SSRT was conducted under two different hydrogen charging conditions:

I. Potentiostatic at $-1.05 \mathrm{~V}_{\mathrm{Ag} / \mathrm{AgCl}}$.

II. Galvanostatic at approximately $-15 \mathrm{~mA} \mathrm{~cm}^{-2}$, corresponding to a cathodic potential of about $-2 \mathrm{~V}_{\mathrm{Ag} / \mathrm{AgCl}}$ irrespective of $\mathrm{Ni}$ content. This condition is referred to as $-2 \mathrm{~V}_{\mathrm{Ag} / \mathrm{AgCl}}$ throughout this paper.

Potentiostatic tests were performed under aerated conditions. In contrast, galvanostatic tests were carried out in deaerated electrolytes. Purging was done by flowing nitrogen continuously. However, since the CE was placed in the same compartment as the SSRT, some oxygen would undeniably have been present in the electrolyte, as oxygen gas evolves at the CE from the direct oxidation of water.

Samples were pre-charged for $48 \mathrm{~h}$ in the potentiostatic tests and $24 \mathrm{~h}$ in the galvanostatic tests before straining. Pre-charging was performed with the sample mounted, but unloaded, inside the SSRT equipment. The electrolyte was not replenished before or during straining. Precharging was done to ensure that all the samples had reached their 
equilibrium concentration of hydrogen before the straining started. Previous permeation tests ${ }^{23}$ on samples with the same composition and microstructures showed that the hydrogen diffusion rate varied with the Ni content of the alloys. Without pre-charging the samples, the SSRT results could be directly influenced by the different hydrogen diffusion rates of the materials. The $3 \mathrm{wt} \% \mathrm{Ni}$ material had the lowest effective diffusion coefficient, $D_{\text {eff }}{ }^{32}$ with a value of $2.5710^{-6} \mathrm{~cm}^{2} \mathrm{~s}^{-1}$ when tested at $15^{\circ} \mathrm{C}$ with galvanostatic hydrogen charging in $0.1 \mathrm{M}$ $\mathrm{NaOH} .{ }^{23}$ Crank's $^{33}$ solution to Fick's second law for a thin plate, showed that 24 hours pre-charge ensured $>99.9999 \%$ of the equilibrium hydrogen concentration through-thickness in all samples. Using the effective diffusion coefficient at $15^{\circ} \mathrm{C}$, as well as the diffusion equation for a thin plate, provide conservative estimates of the hydrogen saturation at the center of a tensile rod at $24^{\circ} \mathrm{C}$.

When performing SSRT, the choice of strain rate is a compromise between the time required to observe a given process, e.g., hydrogen absorption and diffusion to the fracture process zone, and avoiding excessive test duration. ${ }^{20,28,34}$ The strain rate was $10^{-6} \mathrm{~s}^{-1}$ in all tests, which was found by preliminary testing (not shown) on spare samples to be adequate. This strain rate is in line with standard recommendations ${ }^{20,28,34}$ and strain rates used in similar research by others. ${ }^{17,} 30,35$ Since the preliminary samples all exhibited HSC, SSRT was considered as an adequate technique to rank the relative performance vs. Ni content.

One sample of each $\mathrm{Ni}$ content was tested in air, constituting the baseline to which the results from samples tested with hydrogen were compared. The baseline samples were prepared identically to the charged samples and tested following the same procedure. Two samples of each $\mathrm{Ni}$ content were tested per condition.

SSRT was conducted in a conventional tensile frame. The apparatus included an electrochemical cell so that hydrogen charging could be continued during straining of the sample. The full setup is seen in Figure 2. The sample was mounted in the equipment by connecting nuts to the threads on each side of the sample. The nuts were held by spherical bearings to ensure axial tensile stress within the gauge length. All metallic parts of the equipment exposed to the electrolyte were made of UNS N10276. The polymer lid and bottom was made from polyvinylidene fluoride (PVDF).

Using an extensometer during in situ testing is impractical due to the presence of the electrolyte, and was not done in any of the SSRT. Thus, the tensile machine strained the sample at the specified strain rate understood as the movement of its own drivetrain. Consequently, the recorded sample elongation included the machine compliance. To circumvent this problem, NACE TM0198 ${ }^{28}$ recommends that the plastic elongation of the samples is evaluated rather than the total elongation. Once the material yields, most of the displacement is associated with the plastic deformation of the gauge section. ${ }^{28}$ The most pronounced consequence includes a non-linear behavior in the elastic region, which makes estimating the modulus of elasticity impossible.

The SSRT setup used metallic holders as seen in Figure 2. During the potentiostatic tests, the electrical connection to the sample was obtained through the tensile rods outside the electrolyte and the entire assembly was cathodically polarized, together with the sample, to $-1.05 \mathrm{~V}_{\mathrm{Ag} / \mathrm{AgCl}}$. However, in galvanostatic tests the tensile sample was insulated from the holders using ceramic disks to reduce the magnitude of the required total current, and wires were connected directly to both sides of the sample at the connecting nuts. The current density in the galvanostatic tests was estimated by dividing the total applied current by the estimated surface area of the sample and the connecting nuts together.

Evaluation of the results:

The results of SSRT were evaluated according to the recommendations in ASTM G12934 and NACE TM0198 ${ }^{28}$. The criteria are listed below, I) to IV):

I. Reduction in area ratio (RRA). This is defined by Equation (1) as the ratio of reduction in cross-sectional area after fracture in the test environment, $R A_{e}$, to the reduction in cross-sectional area after fracture in a neutral control environment, i.e., air in this investigation, $R A_{c}$. RA for a circular fracture surface is given by Equation (2), where $D_{i}$ is the initial gauge section diameter and $D_{f}$ is the diameter of the fracture surface. The diameter of the gauge section was measured with a caliper prior to the experiments to account for variations between the samples. The diameter was measured at three locations along the gauge section with a precision of $0.01 \mathrm{~mm}$. Two measurements were taken perpendicular to each other at each location, i.e., a total of 6 measurements, and averaged to give $D_{i}$. The diameter of a fracture surface was measured in the SEM by two measurements normal to each other. Two fracture surfaces result from each fractured sample and all four of the measured diameters were averaged to give $D_{f}$.

$$
\begin{gathered}
R R A=\frac{R A_{e}}{R A_{c}} \\
R A=\frac{D_{i}^{2}-D_{f}^{2}}{D_{i}^{2}}
\end{gathered}
$$

II. Plastic elongation ratio (RE). The plastic elongation ratio is defined by Equation (3) as the ratio of plastic elongation to fracture in the test environment, $E_{e}$, to the plastic elongation in the control environment, i.e. air, $E_{c}$. Plastic elongation was recorded by the SSRT software.

$$
R E=\frac{E_{e}}{E_{c}}
$$

III. Toughness/fracture energy ratio. The toughness of the samples was estimated by the area under the engineering stress-strain curves excluding the elastic portion/resilience of the curves. ${ }^{36}$ The toughness ratio was found by dividing the toughness value obtained in the test environment to the value in the control environment, i.e., air.

IV. Visual examination and fractography. Both halves of all fractured samples were examined in the SEM to characterize the type of fracture. All gauge sections were examined for secondary cracking. To obtain more information about the crack initiation and propagation 
and the link to microstructure, additional examinations were performed on 0 and $2 \mathrm{wt} \% \mathrm{Ni}$ samples tested at both $-1.05 \mathrm{~V}_{\mathrm{Ag} / \mathrm{AgCl}}$ and $-2 \mathrm{~V}_{\mathrm{Ag} / \mathrm{AgCl}}$. The reason for not selecting the extremes of $\mathrm{Ni}$ content was that the $2 \mathrm{wt} \%$ $\mathrm{Ni}$ material had a microstructure closer to $0 \mathrm{wt} \% \mathrm{Ni}$ than that of the $3 \mathrm{wt} \% \mathrm{Ni}$ material, thus, facilitating the comparison of the direct effect of $\mathrm{Ni}$ in solid solution. The microstructure around the secondary cracks found at the outer surface were revealed by electropolishing as already described in the section for heat treatment and characterization, without the preceding preparation by grinding and polishing. In addition, fractured samples were ground with abrasive paper to make cross-sections parallel to the loading direction, which were electropolished to reveal the microstructure around the internal secondary cracks. Energy dispersive spectroscopy (EDS) with an acceleration voltage of $5 \mathrm{kV}$ was used to determine chemical composition of particles found in the fracture surfaces of SSRT samples.

As explained in ASTM G129, the assessment of HSC resistance is based on "the decrease in the value of the SSR ratios from unity." In general, lower ratio values indicate increasing susceptibility to environmentally assisted cracking (EAC). ${ }^{34}$

\section{Hydrogen permeation}

Electrochemical hydrogen permeation experiments as described by ISO $17081^{32}$ and ASTM G148 ${ }^{37}$ were carried out to determine the hydrogen concentration in lattice and reversible trap sites, $\mathrm{C}_{\mathrm{OR}}$, for the 0 and 3 wt\% Ni materials under similar charging conditions as for SSRT. Details of the experimental setup are described elsewhere. ${ }^{23}$

Samples of 0 and 3 wt\% Ni were prepared as described by Husby et al, ${ }^{23}$ including the electrodeposition of a Pd layer with thickness in the $0.1 \mu \mathrm{m}$ range on the sample surface on the anodic side. Previous testing did not reveal any irreversible hydrogen trapping in these LAS. ${ }^{23}$ Sample thicknesses were about $1.1 \mathrm{~mm}$. Ideally, different sample thicknesses are tested to check whether bulk diffusion or surface processes control hydrogen transport. ${ }^{38,} 39$ Above a minimum thickness, bulk diffusion is the slowest process and hence controls hydrogen transport; this minimum thickness is a function of the diffusion coefficient, among other experimental parameters. ${ }^{39}$ Recently, Ha et al. ${ }^{38}$ reported that in a ferritic/pearlitic steel the transition occurred at $480 \mu \mathrm{m}$ for effective diffusion coefficient, $D_{\text {eff, }}$ values similar to the ones measured in this work. Therefore, considering that the sample thickness adopted in this work doubled this critical thickness, it is reasonable to assume a priori that experiments were under diffusion-controlled hydrogen transport.

Permeation tests were carried out at $23.0 \pm 0.1^{\circ} \mathrm{C}$. The cathodic compartment was filled with $3.5 \mathrm{wt} \% \mathrm{NaCl}$ electrolyte, and $0.1 \mathrm{M}$ $\mathrm{NaOH}$ electrolyte was used in the anodic compartment. First, the $0.1 \mathrm{M}$ $\mathrm{NaOH}$ electrolyte was added to the anodic compartment and a potential of $+300 \mathrm{mV}_{\mathrm{SCE}}$ was applied. While a stable background current density was obtained on the anodic side, nitrogen gas was purged through the cathodic compartment to minimize oxide formation on the sample surface. After 3 hours, the background current density had stabilized and the aerated $3.5 \mathrm{wt} \% \mathrm{NaCl}$ electrolyte was poured into the cathodic compartment. The sample surface in the cathodic compartment was immediately polarized to $-1.05 \mathrm{~V}_{\mathrm{Ag} / \mathrm{AgCl}}$. The cathodic compartment was not deaerated during the potentiostatic polarization. When the permeation current density reached steady state, deaeration of the electrolyte in the cathodic compartment commenced by nitrogen purging. After 20 minutes deaeration, the hydrogen evolution rate on the cathodic side was stepped up to a galvanostatic current density of $-5 \mathrm{~mA} \mathrm{~cm}^{-2}$. This current density corresponded to a potential around $-1.40 \mathrm{~V}_{\mathrm{Ag} / \mathrm{AgCl}}$. When the permeation current density stabilized, the hydrogen evolution rate was stepped up to $-30 \mathrm{~mA} \mathrm{~cm}^{-2}$. The applied current density corresponded

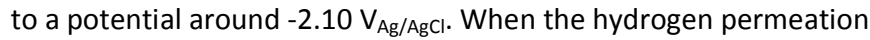
current density stabilized, the experiment was stopped. $D_{\text {eff }}$ values were calculated from the first permeation transients, when polarized to $-1.05 \mathrm{~V}_{\mathrm{Ag} / \mathrm{AgCl}}$, using all three methods $-\mathrm{t}_{\mathrm{lag}}$, $\mathrm{t}_{\mathrm{b}}$ and slope - described in ASTM G148. ${ }^{37}$ For the slope method, a portion of the rise transient was fitted in a manner described by Ha et al. ${ }^{38}$

With the measured steady-state permeation current densities and the determined values for $D_{\text {eff, }} C_{O R}$ values (from three different $D_{\text {eff }}$ values for each sample) were calculated by re-arrangement of Equation (4). ${ }^{32}$

$$
J_{s S}=\frac{I_{s S}}{F A}=\frac{D_{e f f} C_{O R}}{L}
$$

Where $I_{s s}$ is the measured steady-state permeation current in Amperes and $\mathrm{J}_{\text {ss }}$ is the corresponding steady-state hydrogen flux in $\mathrm{mol} \mathrm{cm} \mathrm{cm}^{-2} \mathrm{~s}^{-1}$. $\mathrm{F}$ is Faradays constant equal to $96485 \mathrm{C} \mathrm{mol}^{-1} .{ }^{40} \mathrm{~A}$ is the exposed sample area in $\mathrm{cm}^{2}$ and $L$ is the sample thickness in $\mathrm{cm}$. $D_{\text {eff }}$ is the effective diffusion coefficient in $\mathrm{cm}^{2} \mathrm{~s}^{-1}$ and $\mathrm{C}_{\mathrm{OR}}$ is the sub-surface hydrogen concentration in lattice and reversible trap sites in $\mathrm{mol} \mathrm{cm}^{-3}$. The unit of $\mathrm{C}_{\mathrm{OR}}$ was converted from $\mathrm{mol} \mathrm{cm}^{-3}$ to $\mathrm{ppm}$ (wt) by multiplying with the atomic weight of hydrogen, $1.008 \mathrm{~g} \mathrm{~mol}^{-1},{ }^{40}$ dividing by the density of iron, $7.9 \mathrm{~g} \mathrm{~cm}^{-3}, 40$ and multiplying by $10^{6}$.

\section{Results}

\section{Microstructural characterization}

The microstructures of the tested SSRT samples are shown in Figure 3. The effect of $\mathrm{Ni}$ in refining the microstructure is clearly seen in the difference in grain size from 0 to $1 \mathrm{wt} \% \mathrm{Ni}$, since they were heat treated following identical procedures. In contrast, samples with 2 and $3 \mathrm{wt} \% \mathrm{Ni}$ were given an additional heat treatment with the result that the grain size of the $2 \mathrm{wt} \% \mathrm{Ni}$ samples fell in between the grain sizes of the 0 and $1 \mathrm{wt} \% \mathrm{Ni}$ samples. As explained elsewhere, ${ }^{23}$ the additional heat treatment step was required to obtain comparable microstructures in all LAS, independent of their Ni content. The ASTM grain size no., as determined in Husby et al..$^{23}$ were in the order of increasing Ni content: 8.4, 9.3, 8.8 and 9.1.

The pearlite fraction increased with increasing Ni content, from about 0.20 for the $\mathrm{Ni}$-free control to 0.30 in the $3 \mathrm{wt} \% \mathrm{Ni}$ samples. ${ }^{23}$ The mean true interlamellar pearlite spacing of the materials decreased in the following order: 0 wt\% Ni, 2 wt $\% \mathrm{Ni}, 1$ wt\% Ni and 3 wt $\% \mathrm{Ni}$. The values can be found elsewhere. ${ }^{23}$

The $3 \mathrm{wt} \% \mathrm{Ni}$ samples had a fraction of acicular microconstituents, which are illustrated in Figure 4. Acicular features could only be seen in a few locations in the 2 wt\% $\mathrm{Ni}$ specimens. As explained by Husby et al., ${ }^{23}$ the acicular and disordered microstructure found in the $3 \mathrm{wt} \% \mathrm{Ni}$ material made the quantification of grain size, pearlite content, and interlamellar pearlite spacing difficult and less accurate than in the other LAS samples.

\section{Polarization curves}

The OCP values after one hour stabilization prior to the polarization curves were -739 and $-716 \mathrm{mV}_{\mathrm{Ag} / \mathrm{AgCl}}$ for 0 and 3 wt\% Ni samples, respectively. Figure 5 shows the polarization curves of 0 and $3 \mathrm{wt} \% \mathrm{Ni}$ 
LAS in deaerated $3.5 \mathrm{wt} \% \mathrm{NaCl}$ solution. At potentials more positive than the OCP, the $0 \mathrm{wt} \% \mathrm{Ni}$ sample generally had a larger anodic current density than the $3 \mathrm{wt} \% \mathrm{Ni}$ sample. The cathodic current density, representing hydrogen evolution, was largest for the $3 \mathrm{wt} \% \mathrm{Ni}$ sample. At $-1.05 \mathrm{~V}_{\mathrm{Ag} / \mathrm{AgCl}}$ the cathodic current density was $-0.67 \mathrm{~mA} \mathrm{~cm}^{-2}$ for the $0 \mathrm{wt} \% \mathrm{Ni}$ sample and $-0.95 \mathrm{~mA} \mathrm{~cm}^{-2}$ for the $3 \mathrm{wt} \% \mathrm{Ni}$ sample; a $40 \%$ difference. These results were in good agreement with Kappes et al. ${ }^{41}$ who investigated the electrochemical behavior of $\mathrm{Ni}$-containing LAS in deaerated NACE Test Solution A, i.e., $5 \% \mathrm{NaCl}+0.5 \%$ acetic acid.

\section{Slow strain rate test results in air}

Figure 6 a) shows the SSRT engineering stress strain curves for all the baseline samples in air. The tensile strength (TS) increased with increasing $\mathrm{Ni}$-content. All alloys except that with $3 \mathrm{wt} \% \mathrm{Ni}$ exhibited a strain aging characteristic/Lüders bands, ${ }^{36}$ including upper and lower yield points. The upper yield point is the stress where the transition from elastic to plastic elongation occurs, while the lower yield point is the more or less constant value that the stress fluctuates around before rising at increasing strain, ${ }^{36}$ as indicated by the arrows in Figure 6 b) for the 0, 1 and $2 \mathrm{wt} \% \mathrm{Ni}$ samples. Both upper and lower yield points were at the lowest stresses for 0 wt\% Ni sample. However, the upper yield points for both 1 and $2 \mathrm{wt} \% \mathrm{Ni}$ samples, as well as the proportional limit ${ }^{36}$ for the $3 \mathrm{wt} \% \mathrm{Ni}$ sample, were at approximately the same stress level as seen in Figure $6 \mathrm{~b}$ ). The elongation to failure decreased with increasing Ni content, except for the $1 \mathrm{wt} \%$ Ni sample, which had the highest ductility. The toughness of the samples tested in air were lowest for the $0 \mathrm{wt} \% \mathrm{Ni}$ sample while it was quite similar for the other Ni contents. The values were as follows in the order of increasing Ni content: 112, 138, 133 and $131 \mathrm{MJ} \mathrm{m}^{-3}$.

\section{Hydrogen stress cracking resistance}

Figure 7 compares the results of the SSRT in air and at $-1.05 \mathrm{~V}_{\mathrm{Ag} / \mathrm{AgCl}}$ and $-2 \mathrm{~V}_{\mathrm{Ag} / \mathrm{AgCl}}$ in $3.5 \mathrm{wt} \% \mathrm{NaCl}$. The results for the $3 \mathrm{wt} \% \mathrm{Ni}$ LAS tested at $1.05 \mathrm{~V}_{\mathrm{Ag} / \mathrm{AgCl}}$ showed a difference in elongation between the parallels of about 0.04 , but the differences between parallels were generally below elongation values of 0.02 .

The curves for the hydrogen charged materials were shifted towards slightly higher stresses, which is described as hydrogen hardening, as explained by Hirth. ${ }^{42}$ The lower YS and the TS increased with increasing hydrogen content (lower potential) in the materials. The upper YS on the other hand, increased when the samples were tested at -1.05 $\mathrm{V}_{\mathrm{Ag} / \mathrm{AgCl}}$, but became the same as in air or lower when the samples were tested at $-2 \mathrm{~V}_{\mathrm{Ag} / \mathrm{AgCl}}$. Likewise, no clear trend of hydrogen strengthening as a function of $\mathrm{Ni}$ content was seen.

When tested at $-1.05 \mathrm{~V}_{\mathrm{Ag} / \mathrm{AgCl}}$, all samples fractured after the maximum in engineering stress, with some extent of necking after significant plastic deformation. When tested at $-2 \mathrm{~V}_{\mathrm{Ag} / \mathrm{AgCl}}$, samples fractured closer to the maximum in engineering stress.

RRA values, Equation (1), and RE values, Equation (3), for all samples are shown in Figure $8 a$ ) and $b$ ), respectively. When tested at -1.05 $\mathrm{V}_{\mathrm{Ag} / \mathrm{AgCl}}, \mathrm{RE}$ was highest for the $0 \mathrm{wt} \% \mathrm{Ni}$ material, but did not decrease with increasing Ni content above 1 wt\%. However, when tested at -2 $\mathrm{V}_{\mathrm{Ag} / \mathrm{AgCl}}, \mathrm{RE}$ decreased with every increase in Ni content. RRA values confirmed the trends with minor difference between the materials when tested at $-1.05 \mathrm{~V}_{\mathrm{Ag} / \mathrm{AgCl}}$, but with a negative effect with increasing $\mathrm{Ni}$ content for samples tested at $-2 \mathrm{~V}_{\mathrm{Ag} / \mathrm{AgCl} \text {. }}$

The toughness ratios of the tested samples, i.e. relative to air, are shown in Figure 9. The toughness ratios followed the same trend as RE seen in Figure 8 with a decrease with increasing Ni content when tested at $-2 \mathrm{~V}_{\mathrm{Ag} / \mathrm{AgCl} \text {. }}$

\section{Visual inspection and fractography}

All fracture surfaces in air showed ductile rupture with cup and cone appearance for the two fractured parts. The fracture surfaces were normal to the applied load with local variations in height. When tested with hydrogen charging, both at $-1.05 \mathrm{~V}_{\mathrm{Ag} / \mathrm{AgCl}}$ and $-2 \mathrm{~V}_{\mathrm{Ag} / \mathrm{AgCl}}$, the samples fractured in most cases at an angle close to $45^{\circ}$ to the applied load, with no cup and cone appearance. Figure 10 illustrates the cone shape of an air fractured sample and the angular fracture of a sample tested with hydrogen charging. The reduction in cross-sectional area was larger for the air-tested samples. The hydrogen charged samples had secondary cracks on the circumference of the gauge section as shown in Figure 10. There was no clear difference in the number of secondary cracks close to the fracture surface between the two potential levels. However, more secondary cracks were seen down the gage section away from the fracture surface for the tests carried out at $-2 \mathrm{~V}_{\mathrm{Ag} / \mathrm{AgCl}}$. Most importantly, no trend was found between Ni content and the number of secondary cracks when tested at $-1.05 \mathrm{VAg} / \mathrm{AgCl}$ and $-2 \mathrm{~V}_{\mathrm{Ag} / \mathrm{AgCl}}$

All samples were cut on the lathe to obtain their final shape. The plastic deformation introduced by this process influenced the observed $\mathrm{HSC}$ response, which became apparent when testing at $-2 \mathrm{~V}_{\mathrm{Ag} / \mathrm{AgCl}}$. Figure 11 shows long secondary cracks, formed at the circumference of the gauge section, presumably following deformation bands. Secondary cracks like this one were found in all the samples tested at $-2 \mathrm{~V}_{\mathrm{Ag} / \mathrm{AgCl}}$, regardless of $\mathrm{Ni}$ content. In other words, the artifacts from the machining step affected all cases equally. Two samples (one of 1 $w t \% \mathrm{Ni}$ and one of $3 \mathrm{wt} \% \mathrm{Ni}$ ) had fracture lines following the deformation bands with lengths above $0.3 \mathrm{~mm}$.

The fracture surfaces of all samples were examined in the SEM. Figure 12 a) illustrates the typical surface of a sample tested in air, showing ductile behavior with characteristic dimples. Figure $12 \mathrm{~b}$ ) shows the fracture surface of a $1 \mathrm{wt} \% \mathrm{Ni}$ sample tested at $-1.05 \mathrm{VAg} / \mathrm{AgCl}$, with transgranular cleavage in a large fraction of the surface. Dimples were also present around the cleavage facets. Cleavage surfaces were found in the middle of all samples tested at $-1.05 \mathrm{~V}_{\mathrm{Ag} / \mathrm{AgCl}}$, but a higher fraction of cleavage surfaces was generally found towards the sample edges. When tested at $-2 \mathrm{~V}_{\mathrm{Ag} / \mathrm{AgCl}}$, cleavage facets dominated in all regions. The fracture surfaces were compared between samples of different $\mathrm{Ni}$ content tested at both potentials. No clear differences were found in the morphology of the fracture surfaces as a function of Ni content.

SEM results suggested the presence of "shear cracking" across pearlite colonies as discussed by Enos and Scully, ${ }^{43}$ Figure 13. Shear cracking was found in samples tested both in air and with hydrogen charging, seemingly more often in the hydrogen charged conditions, but never more than a few locations in each sample.

Surface and internal secondary cracks were characterized on 0 and 2 wt\% Ni samples tested at both $-1.05 \mathrm{~V}_{\mathrm{Ag} / \mathrm{AgCl}}$ and $-2 \mathrm{~V}_{\mathrm{Ag} / \mathrm{AgCl}}$ to gain a better understanding of the fracture process and the connection to microstructure as a function of $\mathrm{Ni}$ content. Figure 14 illustrates the difference between a surface, $a$ ), and an internal, $b$ ), secondary crack. The surface secondary cracks were in direct contact with the electrolyte, whereas internal secondary cracks were not.

Secondary cracks were categorized as being in the pearlite, the proeutectoid ferrite, or at the ferrite and pearlite boundary. In the cross-sectional analysis, a minimum of 30 internal secondary cracks were categorized on the 0 and $2 \mathrm{wt} \% \mathrm{Ni}$ samples tested at both -1.05 $\mathrm{V}_{\mathrm{Ag} / \mathrm{AgCl}}$ and $-2 \mathrm{~V}_{\mathrm{Ag} / \mathrm{AgCl}}$. Independently of $\mathrm{Ni}$ content and applied cathodic potential, more than $80 \%$ of the internal cracks were found in 
connection to the pearlite, i.e., in the pearlite or at the boundary between pearlite and proeutectoid ferrite. An example where cracks formed inside the pearlite colonies at three locations, but did not propagate into the ferrite phase, is shown in Figure 15. Most of the internal secondary cracks were not directly inside the pearlite, but at the boundary between ferrite and pearlite, as seen in Figure 16.

The same situation was found when evaluating the surface secondary cracks on the 0 and $2 \mathrm{wt} \% \mathrm{Ni}$ samples, both at $-1.05 \mathrm{VAg} / \mathrm{AgCl}$ and -2 $\mathrm{V}_{\mathrm{Ag} / \mathrm{AgCl}}$. A minimum of 30 surface secondary cracks were categorized on each sample and more than $70 \%$ of the cracks were found in the pearlite or at the boundary between pearlite and proeutectoid ferrite. The same observation was done for both $\mathrm{Ni}$ contents at both hydrogen charging conditions. Figure 17 shows the minority observation of a surface secondary crack located in the middle of the proeutectoid ferrite phase. Nonetheless, the same figure shows a crack at the boundary between pearlite and ferrite.

The cracks were predominantly oriented normal to the loading direction with transgranular propagation. The cracks sometimes propagated along pearlite/proeutectoid ferrite grain boundaries as seen in Figure 16, but proceeded transgranularly when encountering new boundaries.

A few particles were found in the fracture surfaces of all the samples, one example shown in Figure 18. Six of these particles in a $0 \mathrm{wt} \% \mathrm{Ni}$ sample were semi-quantitatively analyzed using EDS. The chemical composition was not the same for all particles, but $\mathrm{Mn}, \mathrm{Si}, \mathrm{Al}, \mathrm{O}$ and $\mathrm{S}$ were detected at concentrations above what was detected in the proeutectoid ferrite or the pearlite.

\section{Hydrogen permeation}

Table 2 shows the steady state hydrogen permeation flux normalized to sample thickness, $\mathrm{J}_{s s} \mathrm{~L}$, for the 0 and $3 \mathrm{wt} \% \mathrm{Ni}$ samples in $3.5 \mathrm{wt} \%$ $\mathrm{NaCl}$ solution with potentiostatic charging to $-1.05 \mathrm{~V}_{\mathrm{Ag} / \mathrm{AgCl}}$ and galvanostatic charging corresponding to potentials of $-1.4 \mathrm{~V}_{\mathrm{Ag} / \mathrm{AgCl}}$ and $2.1 \mathrm{~V}_{\mathrm{Ag} / \mathrm{AgCl}} \mathrm{J}_{\mathrm{ss}} \mathrm{L}$ was highest for the $0 \mathrm{wt} \% \mathrm{Ni}$ material at all hydrogen charging conditions.

$D_{\text {eff }}$ values, determined by $t_{l a g}, t_{b}$ and slope methods, are given in Table 2. Regardless of method of determination, $D_{\text {eff }}$ was about $50 \%$ higher for the 0 wt\% Ni material than for the 3 wt\% Ni material. The value of $D_{\text {eff }}$ for each material differed with the method of determination, as a result of the permeation transients being steeper than predicted by Fick's second law - indicating changing effective diffusivities with time due to significant trap occupancy. ${ }^{32,37}$ In the case of significant trap occupancy, $D_{\text {eff }}$ (and $C_{O R}$ values calculated from Equation (4)) lack a theoretical basis, but are, nevertheless, useful for comparative purposes. ${ }^{32,37,44}$

When tested at $-1.05 \mathrm{~V}_{\mathrm{Ag} / \mathrm{AgCl}}$, the $\mathrm{C}_{\mathrm{OR}}$ value - regardless of method for determining $D_{\text {eff }}$ - for the 3 wt\% Ni material was only $53 \%$ of the $C_{O R}$ value in the $0 \mathrm{wt} \% \mathrm{Ni}$ material, but this percentage increased to $77 \%$ and $91 \%$ when tested at -1.4 and, $-2.1 \mathrm{~V}_{\mathrm{Ag} / \mathrm{AgCl}}$, respectively.

\section{Discussion}

\section{Effect of Ni on physical properties}

The effects of $\mathrm{Ni}$ on the phase equilibria of LAS that explain the variations in microstructure between the samples have been discussed previously. ${ }^{23}$ The discussion below focuses on how the microstructural variations affected the physical properties of the various $\mathrm{Ni}$-containing LAS.
Researchers have developed numerous empirical models to relate steel microstructure and mechanical properties of ferritic/pearlitic steels. The well-known Hall-Petch equation describes the increase in YS with decreasing grain size. ${ }^{45} \mathrm{TS}$ and toughness also increase with decreasing grain size. The pearlite content strongly influences the TS, which increases with increasing pearlite content. ${ }^{45}$ Although the YS is somewhat dependent on the pearlite content, it is primarily determined by the continuous ferrite phase. ${ }^{45}$ Ductility decreases with increasing pearlite content. ${ }^{45} \mathrm{It}$ is generally accepted that $\mathrm{Ni}$ in solid solution gives some contribution to both YS and TS at ambient temperatures. ${ }^{46,47}$ However, the magnitudes of these strength contributions are uncertain. Leslie ${ }^{46}$ reported increases in YS of about 50 and $115 \mathrm{MPa}$ when adding 1.5 and 3 at\% Ni, respectively, to iron. Pickering ${ }^{47}$ found only a few $\mathrm{MPa}$ increase in YS from solid solution hardening when adding up to $2.5 \mathrm{wt} \% \mathrm{Ni}$ in low carbon steels. The accompanied alteration of transformation characteristics when adding solutes has been recognized as a challenge when attempting to quantify solid solution strengthening effects. ${ }^{47}$ With this in mind, no attempt was done to separate the contributions to strength from $\mathrm{Ni}$ in solid solution and pearlite, for the materials in this work. Acicular ferrite, which was found in the 3 wt\% Ni LAS, is known to increase strength, but decrease elongation in ferritic/pearlitic steels. ${ }^{6,48}$

\section{Effect of Ni on HSC resistance}

\section{Fractography}

The fracture surfaces in air had the characteristic cup and cone shapes typical of ductile fracture after tensile testing, as a result of microvoid formation and coalescence in the central region of the sample, followed by the deformation of the outer material along the shear plane. ${ }^{36}$ The characteristic dimples, resulting from microvoid coalescence, were seen in Figure 12, and the fracture mode is referred to as dimple rupture. ${ }^{49}$

Brittle fractures are generally flat and oriented normal to the tensile stress, ${ }^{36,49}$ but the close to $45^{\circ}$ angle seen for the hydrogen charged samples in this work has also been reported by others. ${ }^{50}$ The fracture mode for the samples charged with hydrogen was a mix of transgranular cleavage and dimple rupture. The characteristic feather pattern ${ }^{36}$ of transgranular cleavage is shown in Figure $12 \mathrm{~b}$ ). Dimples caused by microvoid coalescence were present around the cleavage

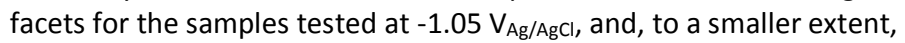
on the samples tested at $-2 \mathrm{~V}_{\mathrm{Ag} / \mathrm{AgCl}}$.

McIntyre ${ }^{51}$ studied crack growth on QT steels with 0.2 and 4.1 wt\% Ni by fracture mechanics testing in gaseous $\mathrm{H}_{2} \mathrm{~S}$ environment. The author found that the steel with $4.1 \mathrm{wt} \% \mathrm{Ni}$ suffered intergranular fracture, while the steel with 0.2 wt\% Ni suffered transgranular fracture. Herein, no difference in the tendency to intergranular fracture with $\mathrm{Ni}$ content was found on the ferritic/pearlitic LAS. There was a tendency for cracks to initiate at the proeutectoid ferrite-pearlite boundaries, Figure 16, but cracks propagated primarily transgranularly. Nevertheless, it is important to emphasize that, in commercial LAS ${ }^{52-54}$ that may contain a larger amount of impurity elements than the research-grade alloys developed for this work, $\mathrm{Ni}$ can promote their segregation to grain boundaries and, therefore, affect the propensity to intergranular decohesive fracture. ${ }^{4}$

Despite the low impurity levels in the LAS studied herein, some inclusions containing $\mathrm{Mn}, \mathrm{Si}, \mathrm{Al}, \mathrm{O}$ and $\mathrm{S}$ were found in the fracture surfaces of all samples, Figure 18. Those elements are typically found in aluminum deoxidized LAS. ${ }^{55}$ The materials manufactured for this project were deoxidized by aluminum addition, and calcium was added for inclusion control. Steel inclusions may potentially affect toughness 
and ductility, but the problem is largely eliminated when calcium is added for inclusion shape control so that the particles are small, rounded, isolated and not deformed. ${ }^{55}$ Additionally, particles were found in all materials, independent of their Ni content. Considering all aspects of the fractographic investigations, no differences were found as a function of $\mathrm{Ni}$ content at any of the test conditions.

\section{Ductility parameters}

The hydrogen-charged samples experienced a hydrogen hardening effect when compared to the baseline cases, as also experienced by e.g. Cabrini et al., ${ }^{56}$ who performed SSRT on API STD 5L X60 steel polarized to -1.05 and $-2 \mathrm{~V}_{\text {SCE }}$ in $3.5 \mathrm{wt} \% \mathrm{NaCl}$. The hardening effect has been discussed previously, e.g., by Hirth. ${ }^{42}$ Different hypothesis exists to explain the occurrence of hydrogen hardening, but just as interesting is why the opposite, i.e., softening, is also often seen. One possible explanation for the hydrogen softening effect is associated with material damage from the hydrogen charging in the form of voids or micro-fissures. In this work, hardening was found on the lower YS for all samples showing Luder bands, and on the TS for all Ni contents, suggesting there was no material damage caused by the hydrogen charging.

The SSRT performance of the LAS in this investigation was comparable to that of Barsanti et al. ${ }^{57}$, who performed SSRT on a Ni-free ferritic/pearlitic LAS in aerated $3.5 \mathrm{wt} \% \mathrm{NaCl}$ solution. The samples were tested at $-1.05 \mathrm{~V}_{\text {SCE }}$ and $-2 \mathrm{~V}_{\text {SCE. }}$. The samples had gauge section diameters of $3 \mathrm{~mm}$ (below the recommended $3.81 \mathrm{~mm}$ in NACE TM0198 ${ }^{28}$ ) and were strained at a rate of $10^{-6} \mathrm{~s}^{-1}$. Details of sample precharging were not provided in the article. The YS and TS of the steel were 430 and $588 \mathrm{MPa}$, respectively. The HSC resistance was evaluated by the RRA, which was 0.55 on average when tested at $-1.05 \mathrm{~V}_{\text {SCE }}$ and 0.25 when tested at $-2 \mathrm{~V}_{\text {SCE. }}$. These values are in good agreement with the RRA-values obtained in the current work, Figure 8.

The polarization curves in Figure 5 showed that the cathodic current density was $40 \%$ larger for the 3 wt\% $\mathrm{Ni}$ samples than for the $0 \mathrm{wt} \% \mathrm{Ni}$

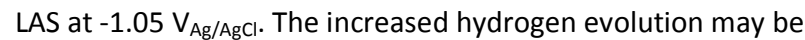
attributed to Ni being more catalytic on the hydrogen evolution reaction than Fe. ${ }^{26}$ Potentiostatic charging would have resulted in a cathodic current that varied as a function of $\mathrm{Ni}$ content, and was the reason for changing from potentiostatic to galvanostatic charging for the tests at $-2 \mathrm{VAg} / \mathrm{AgCl}$.

As discussed in our previous work, ${ }^{23}$ the hydrogen charging severity obtained by cathodic polarization of these LAS to $-1.05 \mathrm{~V}_{\mathrm{Ag} / \mathrm{AgCl}}$ in aerated $3.5 \mathrm{wt} \% \mathrm{NaCl}$ solution was almost a factor of 100 below that obtained in $5 \mathrm{wt} \% \mathrm{NaCl}+0.5 \mathrm{wt} \%$ acetic acid solution with a $\mathrm{H}_{2} \mathrm{~S}$ partial pressure of $101.3 \mathrm{kPa}$ by Kappes et al. ${ }^{58}$ Although still far from an $\mathrm{H}_{2} \mathrm{~S}$ environment charging severity, the tests at $-2 \mathrm{~V}_{\mathrm{Ag} / \mathrm{AgCl}}$, must be considered more relevant for oil and gas production conditions than

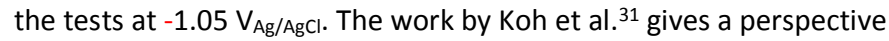
on how a more severe hydrogen charging environment, obtained by $\mathrm{H}_{2} \mathrm{~S}$ exposure, affects SSRT performance. Koh et al. performed SSRT on a ferritic/pearlitic LAS containing $0.25 \mathrm{wt} \% \mathrm{Cu}+\mathrm{Ni}$ (individual amounts of $\mathrm{Cu}$ and $\mathrm{Ni}$ were not specified), which was exposed to $5 \mathrm{wt} \% \mathrm{NaCl}+$ $0.5 \mathrm{wt} \%$ acetic acid saturated with $\mathrm{H}_{2} \mathrm{~S}$. The samples had gauge lengths of $25.4 \mathrm{~mm}$ and diameters of $3.8 \mathrm{~mm}$ as recommended by NACE TM0198 28 , and the cross-head speed was $3 \mu \mathrm{m} \mathrm{min}^{-1}$ (about $210^{-6} \mathrm{~s}^{-1}$ ). The YS of the LAS was just below $500 \mathrm{MPa}$ and the TS was just below $600 \mathrm{MPa}$. The total elongation to failure in air was $30 \%$, while it decreased to $7.5 \%$ in the electrolyte, giving an elongation ratio of 0.25 . As a comparison, the average plastic elongation ratios for the 0 and 3 wt\% $\mathrm{Ni}$ LAS, tested herein at $-2 \mathrm{~V}_{\mathrm{Ag} / \mathrm{AgCl}}$, were 0.56 and 0.36 , respectively. It would be interesting to investigate whether the decreasing $\mathrm{HSC}$ resistance on increasing $\mathrm{Ni}$ content, seen herein when testing at $-2 \mathrm{~V}_{\mathrm{Ag} / \mathrm{AgCl}}$, would be enhanced at more severe hydrogen charging conditions, e.g., in $\mathrm{H}_{2} \mathrm{~S}$-containing electrolytes.

\section{Hydrogen permeation}

The $C_{O R}$ values for the materials herein, Table 2, were in the lower range of what is reported in the literature for hydrogen permeation experiments on LAS with various microstructures in $3.5 \mathrm{wt} \% \mathrm{NaCl}$ and electrolytes simulating seawater when polarized to potentials around 1.05 and $-2 \mathrm{~V}_{\mathrm{Ag} / \mathrm{AgCl}}{ }^{56,59-64}$ According to Equation (4), $\mathrm{C}_{\mathrm{OR}}$ is given by $\mathrm{J}_{\mathrm{SS}} \mathrm{L}$ divided by $D_{\text {eff. }}$. The $J_{s s} L$ values herein, Table 2, were similar to those found by most of the researchers on other LAS in similar charging conditions - calculated from the available results according to Equation (4) - while the $D_{\text {eff }}$ values herein were about an order of magnitude larger than typically reported in the same papers. However, it is well known that $D_{\text {eff }}$ values for similar materials scatter over several orders of magnitude given difference in composition, microstructure, and measurement technique. Since permeation transients are never faster than diffusion allows, it can be argued that the highest value of $D_{\text {eff }}$ for a given material is the most representative, ${ }^{42}$ at a similar charging severity. The $D_{\text {eff }}$ values measured herein were similar to those reported by, e.g., Ha et al. ${ }^{38}$ for an API X-70 steel under similar $\mathrm{J}_{\mathrm{SS}} \mathrm{L}$ values.

Saenz De Santa Maria and Turnbull ${ }^{65}$ found that the SSRT performance of a martensitic stainless steel decreased with increasing values of $J_{s s} L$, obtained by varying the hydrogen charging conditions. This illustrates the now well-established understanding of decreasing HSC/SSC resistance with increasing hydrogen content for a given material. ${ }^{66} \mathrm{As}$ discussed previously, ${ }^{23}$ the effect of $\mathrm{Ni}$ in solid solution on HSC resistance is not revealed by hydrogen permeation experiments alone. However, the permeation results can shed light on the SSRT results under the premise that only hydrogen uptake is affected by Ni alloying.

$J_{s s} L$ was higher for the 0 wt\% Ni sample than for the 3 wt\% Ni LAS under all charging conditions, Table 2. However, the difference in $\mathrm{C}_{\mathrm{OR}}$ between the two materials varied with the balance between $J_{s s} L$ and $D_{\text {eff }}$ according to Equation (4). When tested at $-1.05 \mathrm{~V} / \mathrm{Ag} / \mathrm{AgCl}, \mathrm{C}_{\mathrm{OR}}$ was almost twice as large for the $0 \mathrm{wt} \% \mathrm{Ni}$ LAS as for the $3 \mathrm{wt} \% \mathrm{Ni}$ LAS, while at $-2.1 \mathrm{~V}_{\mathrm{Ag} / \mathrm{AgCl}}$ the $\mathrm{C}_{\mathrm{OR}}$ values were almost equal for the two LAS regardless of which method was used to determine the $D_{\text {eff }}$ value used in Equation (4). The variation in $\mathrm{C}_{\mathrm{OR}}$ values with applied cathodic potential and Ni content may help explain why the RRA, RE and toughness ratio were more negatively affected by $\mathrm{Ni}$ in the SSRT performed at $-2 \mathrm{~V}_{\mathrm{Ag} / \mathrm{AgCl}}$ compared to at $-1.05 \mathrm{~V}_{\mathrm{Ag} / \mathrm{AgCl}}$.

\section{Direct and indirect effects of Ni alloying}

As discussed previously, the microstructures of the LAS used herein had minor disparities concerning grain size, interlamellar pearlite spacing, and pearlite content. Likewise, acicular ferrite was found in the $3 \mathrm{wt} \% \mathrm{Ni}$ samples. The possible influence of each of these variations on HSC resistance is discussed below.

Takasawa et al. ${ }^{67}$ reported improved HSC resistance with decreasing prior austenite grain size (PAGS), while Asahi et al. ${ }^{68}$ and Asahi and Ueno ${ }^{69}$ reported improved SSC resistance with refined PAGS, all for QT LAS. A few attempts have been done to investigate the effect of ferrite grain size on HE resistance. Martinez-Madrid et al. ${ }^{70}$ made tensile samples from pure iron with grain sizes from 35 to $176 \mu \mathrm{m}$ that were pre-charged in $\mathrm{H}_{2} \mathrm{~S}$-saturated $5 \mathrm{wt} \% \mathrm{NaCl}+0.5$ wt\% acetic acid solution for 8 hours and, then, strained at an extension rate of $1 \mathrm{~mm} \mathrm{~min}^{-1}$ in air (sample gauge section diameter and length were not specified). The authors found that the grain boundary angle distribution played a key role. In a normal structure, consisting of both high and low angle grain 
boundaries, there was an optimum grain size of $135 \mu \mathrm{m}$ where loss of ductility was minimized. Asahi et al. ${ }^{71}$ investigated the effect of grain size in steel on SSC resistance by the constant load approach described in NACE TM017729 Method A with a $720 \mathrm{~h}$ exposure time. The electrolyte was $5 \mathrm{wt} \% \mathrm{NaCl}+0.5 \mathrm{wt} \%$ acetic acid saturated with 0.1 $\mathrm{MPa} \mathrm{H}_{2} \mathrm{~S}$. The steel contained 0.11 wt $\% \mathrm{C}$ and was heat treated, by varying the normalization temperature, to ferritic/pearlitic microstructures of three different grain sizes; namely, ASTM no. 9, 7.5 and 6.5. Banding parallel to the loading direction was found in all materials. The YS decreased by about $50 \mathrm{MPa}$ when increasing the grain size from ASTM no. 9 to 6.5. The TS decreased only about 10 $\mathrm{MPa}$. The threshold stress was approximately $220 \mathrm{MPa}$ for all the samples. In other words, the threshold stress to YS ratio decreased with decreasing grain size. The ratio was about $0.75,0.85$ and 0.9 for ASTM no. 9, 7.5 and 6.5, respectively. From the results of MartinezMadrid et al. ${ }^{70}$ and Asahi et al. ${ }^{71}$, HSC resistance should increase with increasing grain size for the LAS investigated herein. Since the grain size did not monotonically decrease with increasing Ni content for all LAS in this work, the decrease in $\mathrm{HSC}$ resistance with increasing $\mathrm{Ni}$ content when testing at $-2 \mathrm{~V}_{\mathrm{Ag} / \mathrm{AgCl}}$ cannot be explained by grain size variations alone.

Koval et al. ${ }^{48}$ assumed, in their discussion about the effect of Ni on SSC resistance, that the promotion of acicular pearlite and ferrite over ferrite/pearlite negatively affected test performance. However, Koh et al. ${ }^{31}$ showed that a ferrite/acicular ferrite microstructure did not decrease SSC resistance compared to a ferrite/pearlite microstructure of the same composition when evaluated by SSRT in an electrolyte containing $\mathrm{H}_{2} \mathrm{~S}$. Investigations by Zhao et al. ${ }^{72}$ also suggested a beneficial effect of acicular ferrite over ultrafine ferrite and ferritic/pearlitic microstructures to SSC resistance - although chemical composition was not fixed in their work. There are no findings suggesting that acicular ferrite as found in the $3 \mathrm{wt} \% \mathrm{Ni}$ LAS, and to a small extent in the $2 \mathrm{wt} \% \mathrm{Ni}$ samples, has a negative impact on HSC resistance.

There are several investigations on the SSC and HSC resistance of ferritic/pearlitic linepipe steel where cracks have been found at the boundary between pearlite and proeutectoid ferrite. ${ }^{73-75}$ Moro et al. ${ }^{75}$ and Kimura et al. ${ }^{73}$ reported cracks along the ferrite/pearlite interfaces in banded microstructures parallel to the loading direction after SSRT and constant load tension tests, respectively. Chan and Charles ${ }^{76}$ found hydrogen induced cracking (HIC) - cracking that results from the pressurization of trap sites by hydrogen, without external stress to the material ${ }^{8}$-along proeutectoid ferrite/pearlite boundaries when charging unloaded samples of homogenized high purity ferritic/pearlitic steel for 48 hours in $\mathrm{H}_{2} \mathrm{~S}$-saturated 5 wt\% $\mathrm{NaCl}+0.5$ $w t \%$ acetic acid solution.

The fact that in this work the HSC resistance decreased with increasing pearlite fraction - which was a function of $\mathrm{Ni}$ content - and that he ferrite-pearlite interface was found to be a critical point for crack initiation in this and previous investigations, suggested that pearlite negatively impacted HSC resistance. However, contradictory work can also be found in the literature. For example, Chan and Charles ${ }^{76}$ concluded that the $\mathrm{HSC}$ resistance of carbon steels increased with increasing pearlite content.

Chan and Charles ${ }^{76}$ investigated the effect of the pearlite fraction on both hydrogen uptake and HSC resistance by varying the carbon content in high purity Fe-C steels. The steels had 0.18, 0.42, 0.59, 0.69 and $0.78 \mathrm{wt} \% \mathrm{C}$, and were homogenized and heat treated to ferritic/pearlitic microstructures. The prior austenite grain size was controlled to approximately $40 \mu \mathrm{m}$ by varying the austenitizing temperatures and times for the different carbon contents. Samples were, then, furnace cooled to room temperature. Different isothermal transformation temperatures below the eutectoid were studied for the 0.59 wt\% C steel to investigate the effect of interlamellar pearlite spacing on hydrogen uptake. Similarly to the LAS used in this investigation, in the work by Chan and Charles samples with up to 0.69 $\mathrm{wt} \% \mathrm{C}$ had a microstructure that consisted of both proeutectoid ferrite and pearlite.

Hydrogen charging was done in a $\mathrm{H}_{2} \mathrm{~S}$-saturated $5 \mathrm{wt} \% \mathrm{NaCl}+0.5 \mathrm{wt} \%$ acetic acid solution for up to 16 hours and the hydrogen content was analyzed by a hot extraction method. The hydrogen content increased with increasing carbon content up to $0.69 \mathrm{wt} \% \mathrm{Ni}$, suggesting that the interface between proeutectoid ferrite and pearlite was an effective hydrogen trapping site. Variations in the interlamellar pearlite spacing from 100 to $500 \mathrm{~nm}$ in the $0.59 \mathrm{wt} \% \mathrm{C}$ steel had little influence on hydrogen uptake, suggesting that the ferrite-cementite interfaces within pearlite colonies were not significant hydrogen trapping sites. Tensile tests were carried out on samples pre-charged with hydrogen in the $\mathrm{H}_{2} \mathrm{~S}$-saturated $5 \mathrm{wt} \% \mathrm{NaCl}+0.5 \mathrm{wt} \%$ acetic acid solution for up to 4 hours. The samples were immediately copper coated after precharging to minimize hydrogen degassing during subsequent testing in air at room temperature. The samples had gauge lengths of $9.56 \mathrm{~mm}$ and diameters of $3.01 \mathrm{~mm}$, and were tested with an extension rate of 1 $\mathrm{mm} \mathrm{min}-1$, i.e., strain rate of $1.7410^{-3} \mathrm{~s}^{-1}$, which was about three orders of magnitude faster than the strain rate used herein. The YS of the materials increased from $253 \mathrm{MPa}$ to $607 \mathrm{MPa}$, and $\mathrm{RA}_{\mathrm{C}}$ decreased from 0.66 to 0.35 , when the carbon content increased from 0.18 to $0.78 w t \%$.

The authors evaluated HSC resistance by the percentage loss in RA. In all cases, a transition from ductile microvoid coalescence when testing in air to cleavage fracture when testing with hydrogen was reported. The corresponding RRA values, Equation (1), increased from about 0.31 to about 0.39 when the carbon content increased from 0.18 to 0.69 wt\% for samples pre-charged for 4 hours, i.e., HSC resistance increased with increasing pearlite fraction. However, the fraction of cleavage increased with increasing pearlite content, which cast doubt on the use of RA and RRA as a reliable estimators of HSC performance. In this regard, today, ASTM G129 recommends the use of fractographic analysis when a large RRA is observed despite a predominant ductile behavior. Therefore, according to ASTM G129, the low-C LAS used by Chan and Charles should have had, in fact, a better HSC performance than their high- $C$ counterparts.

Finally, Chan and Charles ${ }^{76}$ strained without continuous hydrogen charging, had a gage section diameter below that recommended in NACE TM019828 and strained at a high rate. In addition, it is unclear if all the samples were saturated with hydrogen prior to straining. All these factors differ from the experimental approach described herein, questioning the transferability of their results.

Confronting the results presented in the article with the literature suggested that $\mathrm{Ni}$ had an indirect deleterious effect as it increased the pearlite fraction of the steel. It is important to highlight, that most alloying elements, e.g., $\mathrm{Si}, \mathrm{Mn}$ and $\mathrm{Cr}$, are known to have a similar effect. ${ }^{77}$ Nevertheless, it is difficult to separate the consequence of a varying pearlite fraction from that of a direct effect of $\mathrm{Ni}$ in solid solution with conventional SSRT alone. Hence, a firm conclusion on the effect of $\mathrm{Ni}$ in solid solution could not be drawn. In situ tests with high lateral resolution such as electrochemical nanoindentation and focused ion beam (FIB) cut micro-cantilever testing could shed new light into the crack initiation and propagation stages as well as hydrogen-dislocation interactions, ${ }^{3}$ effectively circumventing the effects of $\mathrm{Ni}$ on LAS phase equilibria. Electrochemical nanoindentation testing is the scope of a separate publication. 


\section{Conclusions}

Ferritic/pearlitic low alloy steels, whose chemistries differed only by the nominal Ni contents of $0,1,2$ and $3 \mathrm{wt} \%$, were evaluated by slow strain rate testing with cathodic charging to potentials of -1.05 and -2 $\mathrm{V}_{\mathrm{Ag} / \mathrm{AgCl}}$ in a $3.5 \mathrm{wt} \% \mathrm{NaCl}$ solution with an as prepared $\mathrm{pH}=5.4$ at room temperature. The following conclusions were drawn on the results presented herein:

* The HSC resistance, evaluated by the plastic elongation, reduction in area, and toughness ratios, was not a function of $\mathrm{Ni}$ content above $1 \mathrm{wt} \% \mathrm{Ni}$ when tested at $-1.05 \mathrm{~V}_{\mathrm{Ag} / \mathrm{AgCl}}$. However, when tested at $-2 \mathrm{~V}_{\mathrm{Ag} / \mathrm{AgCl}}, \mathrm{HSC}$ resistance monotonically decreased with increasing $\mathrm{Ni}$ content.

* Independent of $\mathrm{Ni}$ content, the fracture mode changed from only dimple rupture in air to include transgranular cleavage with hydrogen, and the fraction of cleavage was higher when tested at

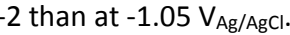

* Most of the secondary cracks in hydrogen-charged samples were found in connection with the pearlite, particularly the boundaries between pro-eutectoid ferrite and pearlite.

* The fraction of pearlite increased from 0.2 to 0.3 with increasing $\mathrm{Ni}$ content from 0 to $3 \mathrm{wt} \%$.

* The fact that the HSC resistance decreased with increasing pearlite fraction - which was a function of Ni content-and that the ferrite-pearlite interface was found to be a critical point for crack initiation, strongly suggested that pearlite negatively impacted HSC resistance. However, existing literature is contradictory and conventional SSRT insufficient to separate the influence of nickel in solid solution from its indirect effect on phase transformation. Thus, no firm conclusion can be drawn regarding the relative influence of $\mathrm{Ni}$ in solid solution versus its indirect role controlling the pearlite fraction on HSC susceptibility.

* More research using in situ techniques with high lateral resolution, e.g., electrochemical nanoindentation, is needed to evaluate the direct effect of $\mathrm{Ni}$ in solid solution.

\section{Acknowledgements}

This work is a part of an international research collaboration between Norwegian University of Science and Technology (NTNU), General Electric (GE), Tenaris, YPF-Technología and the Universidad Nacional de San Martin/Comisión de Energía Atómica (UNSAM/CNEA). The work was financially supported by NTNU and GE. The authors gratefully acknowledge the support of Dr. Alexander Fjeldly and Mr. Atle H. Qvale (GE Oil and Gas), Dr. Teresa Perez and Dr. Martín Valdéz (Tenaris), Dr. Raúl Rebak (GE Global Research Center), Mr Guillermo Carfi, Dr. José Luís Otegui, and Mr. Luis Aguirre (YPF-Technología).

\section{References}

1. IEA, Resources to Reserves 2013, OECD Publishing, 2013).

2. I. Vance, D.R. Thrasher, in Reservoir Souring: Mechanisms and Prevention, eds. O. B, M. M, (Washington, DC: American Society of Microbiology, 2005), p. 123-142.

3. M. Iannuzzi, A. Barnoush, R. Johnsen, npj Materials Degradation 1, 1 (2017):

4. M. Kappes, M. Iannuzzi, R.B. Rebak, R.M. Carranza, Corros. Rev. 32, 3-4 (2014): p. 101-128.
5. C.M. Schillmoller, B.D. Craig, "Nickel Steels in Arctic Service," CORROSION/87, (San Francisco, CA: NACE International, 1987).

6. M.A. Razzak, Bull. Mater. Sci. 34, 7 (2011): p. 1439-1445

7. ISO 15156-2, "Petroleum and natural gas industries Materials for use in $\mathrm{H}_{2} \mathrm{~S}$-containing environments in oil and gas production - Part 2: Cracking-resistant carbon and lowalloy steels, and the use of cast irons" (Geneva, Switzerland: International Organization for Standardization, 2015).

8. ISO 15156-1, "Petroleum and natural gas industries-Materials for use in H2S-containing environments in oil and gas production - Part I: General principles for selection of cracking-resistant materials" (Geneva, Switzerland: International Organization for Standardization, 2015).

9. R. Treseder, T. Swanson, Corrosion 24, 2 (1968): p. 31-37.

10. E. Snape, Corrosion 24, 9 (1968): p. 261-282.

11. H. Asahi, M. Ueno, ISIJ Int. 34, 3 (1994): p. 290-294.

12. B. Craig, Corrosion 44, 11 (1988): p. 776-782.

13.

B. Craig, J. Brownlee, T. Bruno, Corrosion 46, 2 (1990): p. 142 146.

14. B. Craig, J. Brownlee, T. Bruno, Corrosion 48, 2 (1992): p. 9097.

15. B.D. Craig, Corrosion 38, 9 (1982): p. 457-463.

16. A.K. Dunlop, Corrosion 34, 3 (1978): p. 88-96.

17. T. Kaneko, A. Ikeda, Transactions of the Iron and Steel Institute of Japan 28, 7 (1988): p. 575-577.

18. Y. Yamane, N. Totsuka, M. Kimura, T. Kurisu, K. Motada, Y. Nakai, "Effect of Ni on sulfide stress corrosion cracking in low alloy steels," Corrosion, (Houston, TX, USA: NACE International, 1986).

19. Y. Yoshino, Y. Minozaki, Corrosion 42, 4 (1986): p. 222-233.

20. "Corrosion Resistant Alloys for Oil and Gas Production Guidance on General Requirements and Test Methods for H2S Service: (EFC 17 - 2nd Edition)," 2002.

21. W.T. Becker, R.J. Shipley, in ASM Handbook, Volume 11 Failure Analysis and Prevention, ed.ASM International, 2002), p. 691-693.

22. M. Kohno, M. Makioka, S. Kinoshita, A. Suzuki, in Mechanical Properties of Vacuum Carbon-Deoxidized Thick-Wall 21/4Cr1 Mo Steel Forging, eds. G. Sangdahl, M. Semchyshen, vol. STP 755-EB (West Conshohocken, PA: ASTM International, 1982), p. 208-227.

23. H. Husby, M. Iannuzzi, R. Johnsen, M. Kappes, A. Barnoush, Int. J. Hydrogen Energy 43, 7 (2018): p. 3845-3861.

24. C.M. Liao, J.L. Lee, Corrosion 50, 9 (1994): p. 695-704.

25. L.E. Samuels, in Light Microscopy of Carbon Steels, ed.ASM International, 1999), p. 110-118.

26. C. Hamann, A. Hamnett, W. Vielstich, in Electrochemistry, 2nd completely revised and updated ed, ed.Weinheim: Wiley-VCH Pub, 2007), p. 98-102, 212-213.

27. ASTM G61-86(2014), "Standard Test Method for Conducting Cyclic Potentiodynamic Polarization Measurements for Localized Corrosion Susceptibility of Iron-, Nickel-, or CobaltBased Alloys" (West Conshohocken: ASTM International, 2014).

28. TM0198-2011, "Slow Strain Rate Test Method for Screening Corrosion-Resistant Alloys for Stress Corrosion Cracking in Sour Oilfield Service" (Houston, TX: NACE International, 2011).

29. TM0177-2016, "Laboratory Testing of Metals for Resistance to Sulfide Stress Cracking and Stress Corrosion Cracking in H2S Environments" (Houston, TX: NACE International, 2016).

30. W. Hui, H. Zhang, Y. Zhang, X. Zhao, C. Shao, Materials Science and Engineering: A 674 (2016): p. 615-625. 
31. S.U. Koh, J.S. Kim, B.Y. Yang, K.Y. Kim, Corrosion 60, 3 (2004): p. 244-253.

32. ISO 17081:2014, "Method of measurement of hydrogen permeation and determination of hydrogen uptake and transport in metals by an electrochemical technique" (Geneva, Switzerland: International Organization for Standardization, 2014).

33. J. Crank, The mathematics of diffusion, 2nd ed.ed., (Oxford: Clarendon Press, 1975).

34. ASTM G129-00, "Standard Practice for Slow Strain Rate Testing to Evaluate the Susceptibility of Metallic Materials to Environmentally Assisted Cracking" (West Conshohocken: ASTM International, 2013).

35. M.P. LaCoursiere, D.K. Aidun, D.J. Morrison, "Hydrogen Embrittlement of AISI 4340 Using Slow Strain Rate Testing," Corrosion, (San Antonio, TX, USA: NACE International, 2014).

36. A.F. Liu, Mechanics and Mechanisms of Fracture - An Introduction, ASM International, 2005).

37. ASTM G148-97, "Standard Practice for Evaluation of Hydrogen Uptake, Permeation, and Transport in Metals by an Electrochemical Technique" (West Conshohocken: ASTM International, 2011).

38. H.M. Ha, J.-H. Ai, J.R. Scully, Corrosion 70, 2 (2013): p. 166184.

39. J. Kittel, F. Ropital, J. Pellier, Corrosion 64, 10 (2008): p. 788799.

40. G.H. Aylward, T.J.V. Findlay, Sl chemical data, 5th ed.ed., (Milton: Wiley, 2002).

41. M. Kappes, M. Iannuzzi, R.M. Carranza, R.J. Blair, R.B. Rebak, "Electrochemical Behavior of Nickel-Containing LAS in Deaerated TM0177 Solution A," CORROSION 2015, (Dallas, TX: NACE International, 2015).

42. J. Hirth, Metall. Trans. A 11, 6 (1980): p. 861-890.

43. D. Enos, J. Scully, Metallurgical and Materials Transactions A 33, 4 (2002): p. 1151-1166.

44. A. Turnbull, M.W. Carroll, D.H. Ferriss, Acta Metall. 37, 7 (1989): p. 2039-2046.

45. J.R. Davis, in Metals Handbook, Desk Edition (2nd Edition), ed.ASM International, 1998), p. 152-173.

46. W.C. Leslie, Metallurgical Transactions 3, 1 (1972): p. 5-\&.

47. F.B. Pickering, Physical metallurgy and the design of steels, (London: Applied Science Pub., 1978).

48. V. Koval, L. Karvatskii, R. Koval'chuk, Soviet materials science : a transl. of Fiziko-khimicheskaya mekhanika materialov / Academy of Sciences of the Ukrainian SSR 15, 2 (1979): p. 161-164.

49. K. Mills, J.R. Davis, in ASM Handbook, Volume 12 Fractography, ed.ASM International, 1987), p. 12-35, 173178.

50. J. Venezuela, Q. Zhou, Q. Liu, M. Zhang, A. Atrens, Corros. Sci. 111 (2016): p. 602-624.

51. P. Mclntyre, "The Relationships Between Stress Corrosion Cracking and Sub-critical Flaw Growth in Hydrogen and Hydrogen Sulfide Gases," Stress Corrosion Cracking and Hydrogen Embrittlement of Iron Base Alloys, (Firminy, France: National Association of Corrosion Engineers, 1973), p. 788-797.

52. A508/A508M-17, "Standard Specification for Quenched and Tempered Vacuum-Treated Carbon and Alloy Steel Forgings for Pressure Vessels" (West Conshohocken, PA, USA: ASTM International, 2017).

53. ASTM A592/A592M-10(2015), "Standard Specification for High-Strength Quenched and Tempered Low-Alloy Steel Forged Parts for Pressure Vessels" (West Conshohocken, PA, USA: ASTM International, 2015).
54. ASTM A707/A707M-14, "Standard Specification for Forged Carbon and Alloy Steel Flanges for Low-Temperature Service" (West Conshohocken, PA, USA: ASTM International, 2014).

55. D.T. Llewellyn, R.C. Hudd, in Steels - Metallurgy and Applications (3rd Edition), ed.Elsevier, 1998), p. 137-166.

56. M. Cabrini, S. Maffi, G. Razzini, "Evaluation of the hydrogen embrittlement behaviour by means of the permeation current measure in slow strain rate conditions of a microalloyed steel," Materials science forumTrans Tech Publ, 1998), p. $1245-1256$.

57. L. Barsanti, M. Cabrini, T. Pastore, C. Spinelli, in Effect of microstructure on the hydrogen-embrittlement behaviour of HSLA steels under cathodic protection, (Amsterdam: Elsevier, 2008), p. 279-289.

58. M. Kappes, G.S. Frankel, R. Thodla, M. Mueller, N. Sridhar, R.M. Carranza, Corrosion 68, 11 (2012): p. 1015-1028.

59. R. Hamzah, M. Robinson, Corros. Sci. 27, 9 (1987): p. 971979.

60. E. Hörnlund, J. Fossen, S. Hauger, C. Haugen, T. Havn, T. Hemmingsen, Int. J. Electrochem. Sci 2 (2007): p. 82-92.

61. K. Lucas, M. Robinson, Corros. Sci. 26, 9 (1986): p. 705-717.

62. E. Lunarska, J. Birn, P. Domżalicki, Mater. Corros. 58, 1 (2007): p. 13-19.

63. L. Simoni, J.Q. Caselani, L.B. Ramos, R.M. Schroeder, C. de Fraga Malfatti, Corros. Sci. 118 (2017): p. 178-189.

64. T. Zhang, W. Zhao, T. Li, Y. Zhao, Q. Deng, Y. Wang, W. Jiang, Corros. Sci. 131 (2018): p. 104-115.

65. M.S. de Santa Maria, A. Turnbull, Corros. Sci. 29, 1 (1989): p. 69-88.

66. P. Rhodes, L. Skogsberg, R. Tuttle, Corrosion 63, 1 (2007): p. 63-100.

67. K. Takasawa, Y. Wada, R. Ishigaki, R. Kayano, Materials Transactions 51, 2 (2010): p. 347-353.

68. H. Asahi, Y. Sogo, M. Ueno, H. Higashiyama, Corrosion 45, 6 (1989): p. 519-527.

69. H. Asahi, M. Ueno, ISIJ Int. 32, 9 (1992): p. 1021-1026.

70. M. Martinez-Madrid, S.L.I. Chan, J.A. Charles, Mater. Sci. Technol. 1, 6 (1985): p. 454-460.

71. H. Asahi, A. Yagi, M. Ueno, ISIJ Int. 33, 11 (1993): p. 11901195.

72. M.C. Zhao, Y. Shan, F. Xiao, K. Yang, Y. Li, Mater. Lett. 57, 1 (2002): p. 141-145.

73. M. Kimura, N. Totsuka, T. Kurisu, K. Amano, J. Matsuyama, Y. Nakai, Corrosion 45, 4 (1989): p. 340-346.

74. Y. Kobayashi, K. Ume, T. Hyodo, T. Taira, Corros. Sci. 27, 1011 (1987): p. 1117-1135.

75. I. Moro, L. Briottet, P. Lemoine, E. Andrieu, C. Blanc, G. Odemer, Materials Science and Engineering: A 527, 27 (2010): p. 7252-7260.

76. S. Chan, J. Charles, Mater. Sci. Technol. 2, 9 (1986): p. 956962.

77. G. Krauss, in Steels - Processing, Structure, and Performance (2nd Edition), ed.ASM International, 2015), p. 17-38.

78. ASTM E1019-11, "Standard Test Methods for Determination of Carbon, Sulfur, Nitrogen, and Oxygen in Steel, Iron, Nickel, and Cobalt Alloys by Various Combustion and Fusion Techniques" (West Conshohocken: ASTM International, 2011).

79. ASTM E1479-99, "Standard Practice for Describing and Specifying Inductively-Coupled Plasma Atomic Emission Spectrometers" (West Conshohocken: ASTM International, 2011).

\section{FIGURE CAPTIONS}

Figure 1. Dimensions of test samples for SSRT. All numbers are in $\mathrm{mm}$. 
Figure 2. Three electrode electrochemical setup within the SSRT equipment.

Figure 3. SEM micrographs of the SSRT samples from 0 to $3 \mathrm{wt} \% \mathrm{Ni}$ at 1000X magnification.

Figure 4. SEM micrograph of $3 \mathrm{wt} \% \mathrm{Ni}$ at $500 \mathrm{X}$ indicating acicular features.

Figure 5. Polarization curves of 0 and $3 \mathrm{wt} \% \mathrm{Ni}$ LAS in deaerated 3.5 wt $\% \mathrm{NaCl}$ solution at $24 \pm 1^{\circ} \mathrm{C}$. Scan rate of $0.17 \mathrm{mV} \mathrm{s}-1$.

Figure 6. a) SSRT results from baseline tests of LAS with Ni contents from 0 to $3 \mathrm{wt} \%$ performed in air at room temperature. Strain rate of 10-6 s-1. b) Zoom in of the same figure showing the strain aging characteristic/Lüders bands.

Figure 7. Results from SSRT in air and at $-1.05 \mathrm{VAg} / \mathrm{AgCl}$ and $-2 \mathrm{VAg} / \mathrm{AgCl}$ in $3.5 \mathrm{wt} \% \mathrm{NaCl}$ solution at room temperature for LAS with Ni contents from 0 to $3 \mathrm{wt} \% \mathrm{Ni}$ as indicated. Strain rate of 10-6 s-1 in all tests. Figure 8. a) Reduction in area ratios (RRA) and b) plastic elongation ratios (RE) after SSRT of LAS, with Ni contents from 0 to 3 wt\%, in air and at $-1.05 \mathrm{VAg} / \mathrm{AgCl}$ and $-2 \mathrm{VAg} / \mathrm{AgCl}$ in $3.5 \mathrm{wt} \% \mathrm{NaCl}$ solution at room temperature.

Figure 9. Toughness ratios after SSRT on LAS with Ni contents from 0 to $3 \mathrm{wt} \%$, in air and at $-1.05 \mathrm{VAg} / \mathrm{AgCl}$ and $-2 \mathrm{VAg} / \mathrm{AgCl}$ in $3.5 \mathrm{wt} \% \mathrm{NaCl}$ solution at room temperature.

Figure 10. Side view of fractured LAS samples with 1 wt $\%$ Ni after SSRT a) in air and b) at $-1.05 \mathrm{VAg}_{/ \mathrm{AgCl}}$ in aerated $3.5 \mathrm{wt} \% \mathrm{NaCl}$ solution. Figure 11. Secondary cracks formed, presumably, in bands of plastic deformation from machining after SSRT on a $2 \mathrm{wt} \%$ Ni LAS sample tested at $-2 \mathrm{VAg} / \mathrm{AgCl}$ in $3.5 \mathrm{wt} \% \mathrm{NaCl}$ solution.
Figure 12. Fracture surfaces of a 1 wt $\%$ Ni LAS sample after SSRT a) in air and b) at $-1.05 \mathrm{VAg} / \mathrm{AgCl}$ in aerated $3.5 \mathrm{wt} \% \mathrm{NaCl}$ solution.

Figure 13. Fracture surface in a 0 wt $\%$ Ni LAS sample after SSRT at -2 $\mathrm{VAg} / \mathrm{AgCl}$ in $3.5 \mathrm{wt} \% \mathrm{NaCl}$ solution, likely the result of shear cracking across pearlite colonies.

Figure 14. This figure illustrates the difference in crack location for a 0 wt\% Ni LAS sample after SSRT at $-1.05 \mathrm{VAg} / \mathrm{AgCl}$ in aerated $3.5 \mathrm{wt} \% \mathrm{NaCl}$ solution: a) surface secondary cracks and b) internal secondary cracks. In a) the fractured sample was directly electropolished to reveal the microstructure while in b) a cross section of the fractured sample was made before electropolising to reveal the microstructure.

Figure 15. Internal secondary cracks in the pearlite colonies at three locations in a $0 \mathrm{wt} \% \mathrm{Ni}$ LAS sample after SSRT at $-1.05 \mathrm{VAg} / \mathrm{AgCl}$ in aerated $3.5 \mathrm{wt} \% \mathrm{NaCl}$ solution. Arrows indicate the loading direction. Figure 16. Internal secondary crack at the boundary between proeutectoid ferrite and pearlite in a $0 \mathrm{wt} \% \mathrm{Ni}$ LAS sample after SSRT at $-1.05 \mathrm{VAg} / \mathrm{AgCl}$ in aerated $3.5 \mathrm{wt} \% \mathrm{NaCl}$ solution. Arrows indicate the loading direction.

Figure 17. Surface secondary crack in the proeutectoid ferrite phase in a 0 wt\% Ni LAS sample after SSRT at $-2 \mathrm{VAg} / \mathrm{AgCl}$ in $3.5 \mathrm{wt} \% \mathrm{NaCl}$ solution. Arrows indicate the loading direction.

Figure 18. Particle in the fracture surface of a $0 \mathrm{wt} \%$ Ni LAS sample after SSRT at $-1.05 \mathrm{VAg} / \mathrm{AgCl}$ in aerated $3.5 \mathrm{wt} \% \mathrm{NaCl}$ solution. 
Tables

Table 1. Chemical compositions of tested LAS. Analyzed by methods specified in ASTM E1019-11/CO ${ }^{78}$ and ASTM E1479-99/CTP3101/ICP79.

\begin{tabular}{|c|c|c|c|c|c|c|}
\hline Alloy & $\mathbf{N i}[\mathbf{w t} \%]$ & $\mathbf{M n}[\mathbf{w t} \%]$ & $\mathbf{S i}[\mathbf{w t} \%]$ & $\mathbf{C}[\mathbf{w t} \%]$ & X-factor $^{(\mathbf{A})}$ & J-factor $^{(\mathbf{B})}$ \\
\hline $\mathbf{0} \mathbf{w t} \% \mathbf{~ N i}$ & 0.00 & 1.30 & 0.24 & 0.17 & 0.47 & 6.99 \\
\hline $\mathbf{1} \mathbf{w t} \% \mathbf{~ N i}$ & 0.97 & 1.30 & 0.24 & 0.17 & 0.48 & 7.05 \\
\hline $\mathbf{2} \mathbf{w t \%} \mathbf{~ N i}$ & 1.85 & 1.28 & 0.23 & 0.17 & 0.43 & 6.56 \\
\hline $\mathbf{3} \mathbf{w t \%} \mathbf{~ N i}$ & 2.86 & 1.30 & 0.24 & 0.17 & 0.59 & 9.09 \\
\hline \multicolumn{7}{|c|}{100} \\
\hline
\end{tabular}

(B) $(S i+M n) \times(P+S n) 10^{4}$

Table 2. $J_{S S} L, C_{O R}$ and $D_{\text {eff }}$ values - calculated by $t_{\text {lag, }} t_{b}$ and slope methods ${ }^{37}$ - for 0 and $3 w t \%$ Ni samples tested in permeation experiments at $23 \pm$ $0.1^{\circ} \mathrm{C}$ in $3.5 \mathrm{wt} \% \mathrm{NaCl}$ solution under three hydrogen charging conditions.

\begin{tabular}{|c|c|c|c|c|c|c|c|}
\hline \multirow[b]{2}{*}{ Charging condition } & \multicolumn{7}{|c|}{$0 \mathrm{wt} \% \mathrm{Ni}$} \\
\hline & $\begin{array}{l}D_{\text {eff }}\left(t_{\text {lag }}\right) \\
{\left[\mathrm{cm}^{2} \mathrm{~s}^{-1}\right]}\end{array}$ & $\begin{array}{c}D_{\text {eff }}\left(t_{b}\right) \\
{\left[\mathrm{cm}^{2} \mathrm{~s}^{-1}\right]}\end{array}$ & $\begin{array}{c}D_{\text {eff }} \text { (slope) } \\
{\left[\mathrm{cm}^{2} \mathrm{~s}^{-1}\right]}\end{array}$ & $\begin{array}{c}\mathrm{J}_{\mathrm{ss}} \mathrm{L} \\
{\left[\mathrm{mol} \mathrm{cm}^{-1} \mathrm{~s}^{-1}\right]}\end{array}$ & $\begin{array}{c}\mathrm{C}_{\mathrm{OR}}\left(\mathrm{t}_{\mathrm{lag}}\right) \\
{[\mathrm{ppm}(\mathrm{wt})]}\end{array}$ & $\begin{array}{c}\mathrm{C}_{\mathrm{OR}}\left(\mathrm{t}_{\mathrm{b}}\right) \\
{[\mathrm{ppm}(\mathrm{wt})]}\end{array}$ & $\begin{array}{l}\mathrm{C}_{\mathrm{OR}} \text { (slope) } \\
{[\mathrm{ppm}(\mathrm{wt})]}\end{array}$ \\
\hline $\begin{array}{l}\text { Potentiostatic } \\
-1.05 \mathrm{~V}_{\mathrm{Ag} / \mathrm{AgCl}}\end{array}$ & \multirow{3}{*}{$7.0010^{-6}$} & \multirow{3}{*}{$4.2210^{-6}$} & \multirow{3}{*}{$3.4610^{-6}$} & $5.5110^{-13}$ & 0.0100 & 0.0167 & 0.0203 \\
\hline $\begin{array}{c}\text { Galvanostatic } \\
-5 \mathrm{~mA} \mathrm{~cm}^{-2} \\
\left(-1.4 \mathrm{~V}_{\mathrm{Ag} / \mathrm{AgCl}}\right)\end{array}$ & & & & $1.4410^{-12}$ & 0.0263 & 0.0436 & 0.0531 \\
\hline \multirow[t]{3}{*}{$\begin{array}{l}\text { Galvanostatic } \\
-30 \mathrm{~mA} \mathrm{~cm}^{-2} \\
\left(-2.1 \mathrm{~V}_{\mathrm{Ag} / \mathrm{AgCl}}\right)\end{array}$} & & & & $2.2010^{-12}$ & 0.0401 & 0.0667 & 0.0812 \\
\hline & \multicolumn{7}{|c|}{3 wt\% $\mathrm{Ni}$} \\
\hline & $\begin{array}{l}D_{\text {eff }}\left(t_{\text {lag }}\right) \\
{\left[\mathrm{cm}^{2} \mathrm{~s}^{-1}\right]}\end{array}$ & $\begin{array}{c}D_{\text {eff }}\left(t_{b}\right) \\
{\left[\mathrm{cm}^{2} \mathrm{~s}^{-1}\right]}\end{array}$ & $\begin{array}{c}D_{\text {eff }}(\text { slope) } \\
{\left[\mathrm{cm}^{2} \mathrm{~s}^{-1}\right]}\end{array}$ & $\begin{array}{c}\mathrm{J}_{\mathrm{ss}} \mathrm{L} \\
{\left[\mathrm{mol} \mathrm{cm} \mathrm{cm}^{-1} \mathrm{~s}^{-1}\right]}\end{array}$ & $\begin{array}{c}\mathrm{C}_{\mathrm{OR}} \\
{[\mathrm{ppm}(\mathrm{wt})]}\end{array}$ & $\begin{array}{c}\mathrm{C}_{\mathrm{OR}}\left(\mathrm{t}_{\mathrm{b}}\right) \\
{[\mathrm{ppm}(\mathrm{wt})]}\end{array}$ & $\begin{array}{l}\mathrm{C}_{\mathrm{OR}} \text { (slope) } \\
\text { [ppm(wt)] }\end{array}$ \\
\hline $\begin{array}{l}\text { Potentiostatic } \\
-1.05 \mathrm{~V}_{\mathrm{Ag} / \mathrm{AgCl}}\end{array}$ & \multirow{3}{*}{$4.6210^{-6}$} & \multirow{3}{*}{$2.7810^{-6}$} & \multirow{3}{*}{$2.2710^{-6}$} & $1.9210^{-13}$ & 0.0053 & 0.0088 & 0.0108 \\
\hline $\begin{array}{c}\text { Galvanostatic } \\
-5 \mathrm{~mA} \mathrm{~cm}^{-2} \\
\left(-1.4 \mathrm{~V}_{\mathrm{Ag} / \mathrm{AgCl}}\right)\end{array}$ & & & & $7.3210^{-13}$ & 0.0202 & 0.0336 & 0.0411 \\
\hline $\begin{array}{c}\text { Galvanostatic } \\
-30 \mathrm{~mA} \mathrm{~cm}^{-2} \\
\left(-2.1 \mathrm{~V}_{\mathrm{Ag} / \mathrm{Agcl}}\right)\end{array}$ & & & & $1.3210^{-12}$ & 0.0365 & 0.0607 & 0.0742 \\
\hline
\end{tabular}


Figures

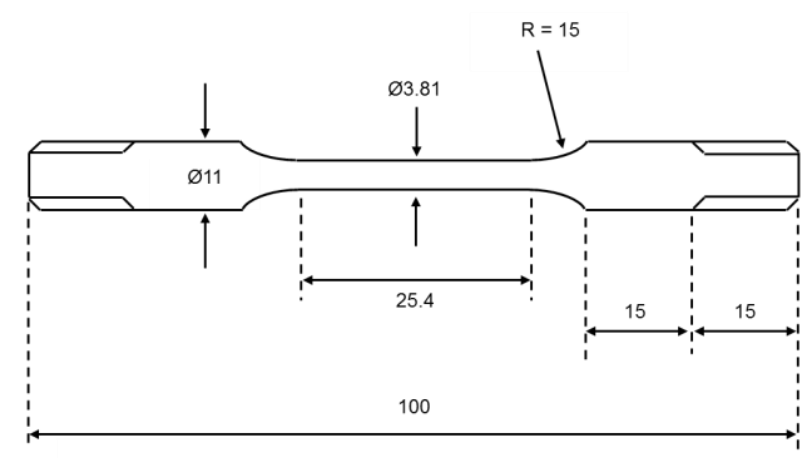

Figure 1. Dimensions of test samples for SSRT. All numbers are in $\mathrm{mm}$.

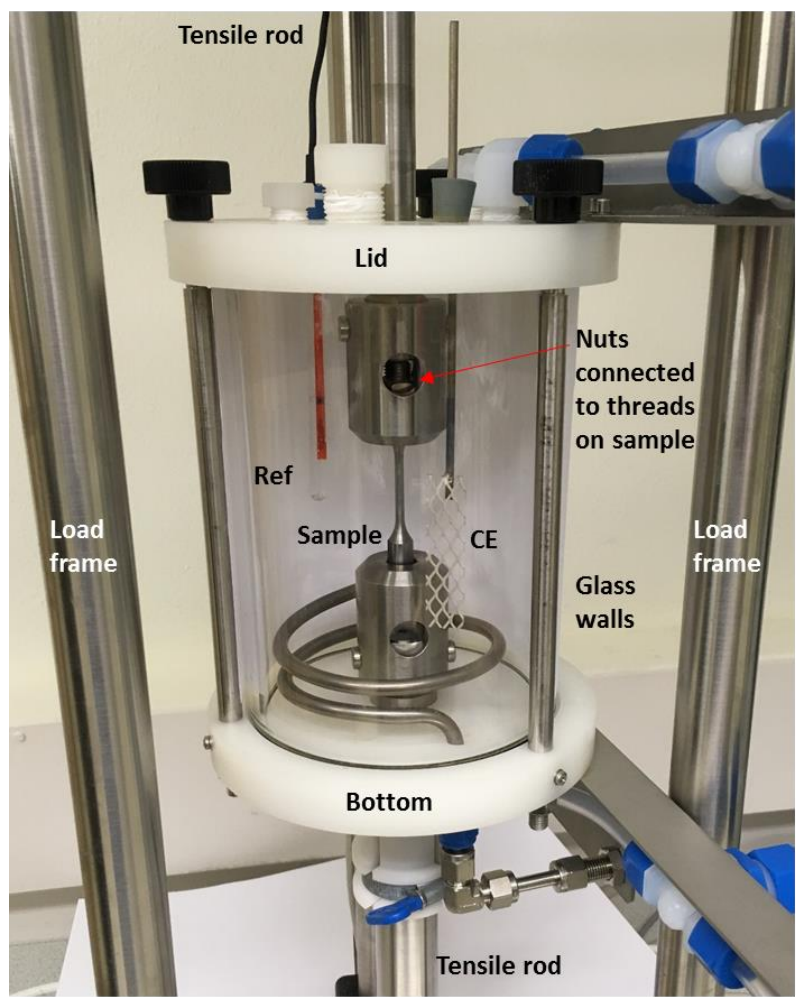

Figure 2. Three electrode electrochemical setup within the SSRT equipment. 


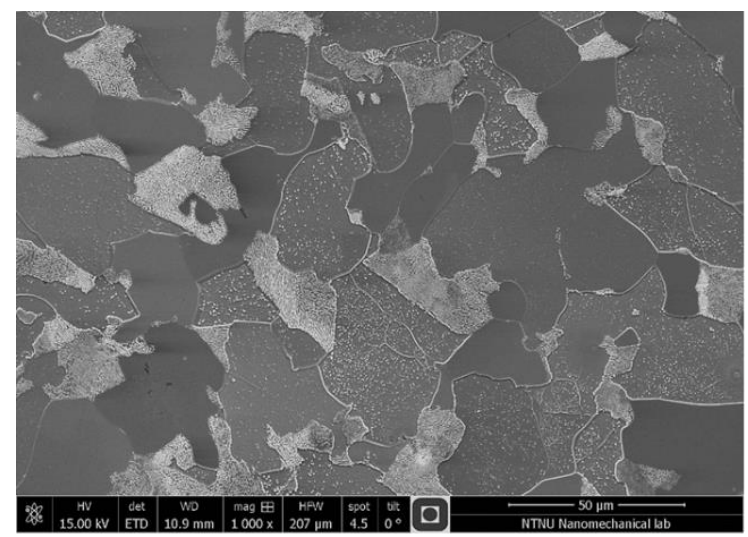

$0 \mathrm{wt} \% \mathrm{Ni}$

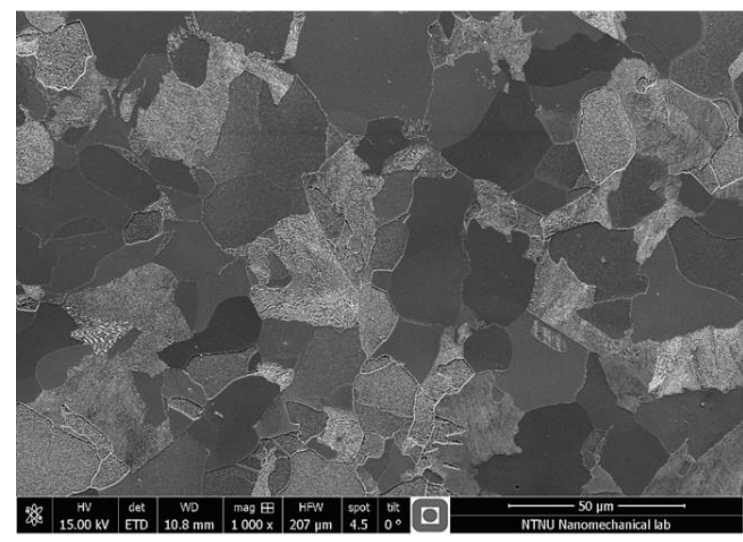

$2 \mathrm{wt} \% \mathrm{Ni}$

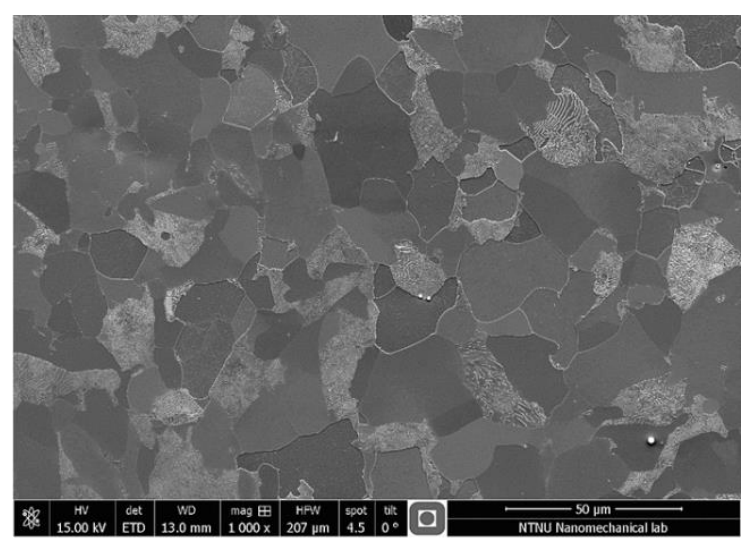

$1 \mathrm{wt} \% \mathrm{Ni}$

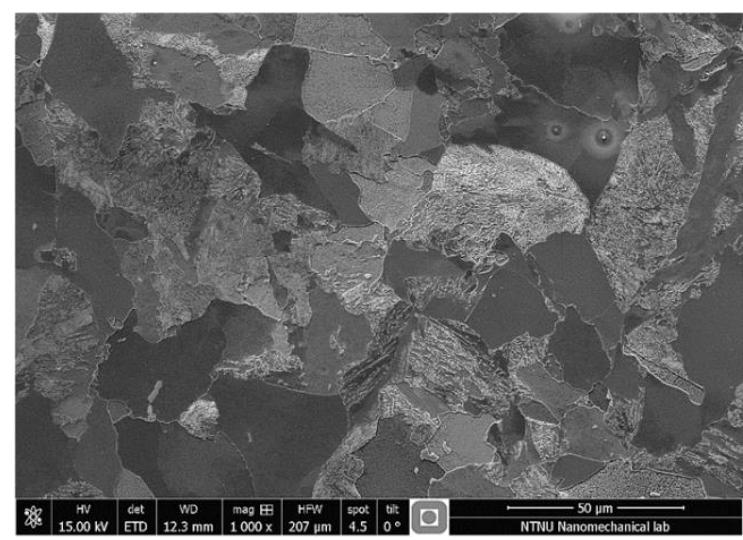

$3 \mathrm{wt} \% \mathrm{Ni}$

Figure 3. SEM micrographs of the SSRT samples from 0 to 3 wt\% Ni at 1000X magnification.

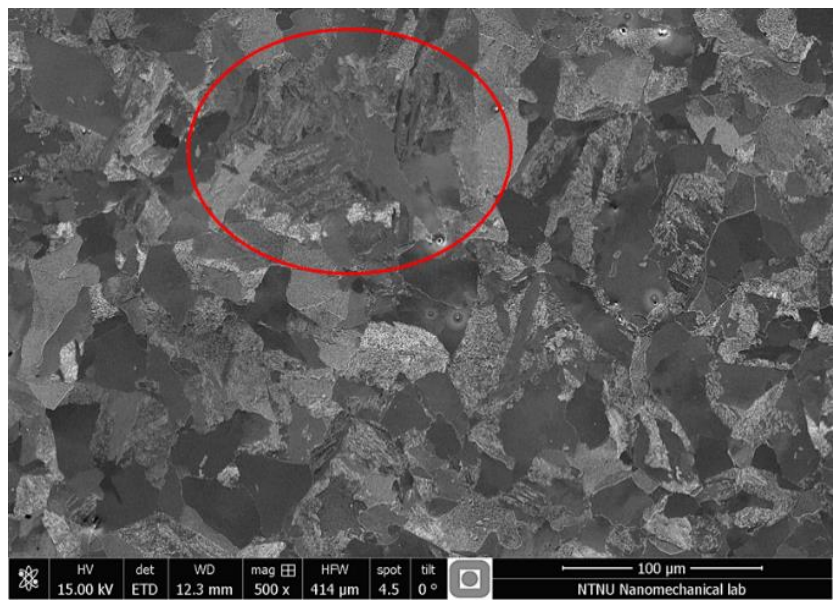

Figure 4. SEM micrograph of $3 w t \%$ Ni at 500X indicating acicular features. 


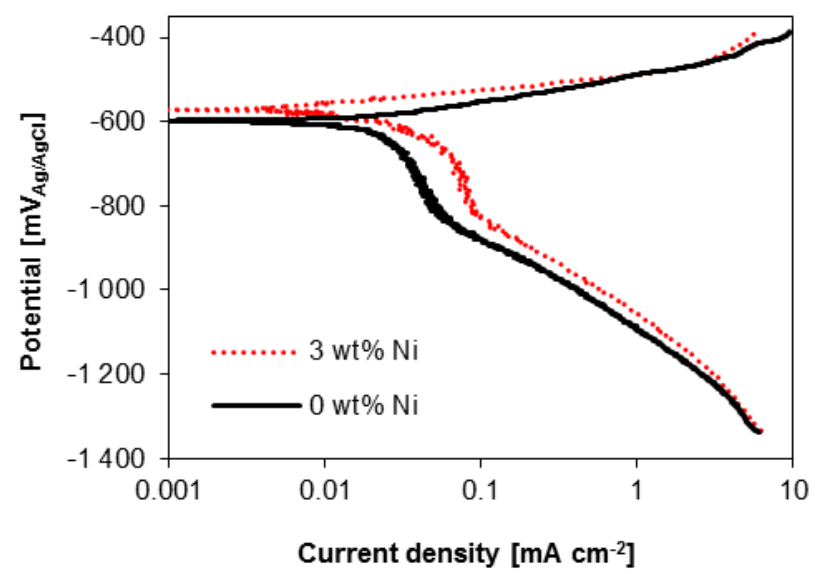

Figure 5. Polarization curves of 0 and $3 w t \%$ Ni LAS in deaerated 3.5 wt\% NaCl solution at $24 \pm 1^{\circ} \mathrm{C}$. Scan rate of $0.17 \mathrm{mV} \mathrm{s}{ }^{-1}$.

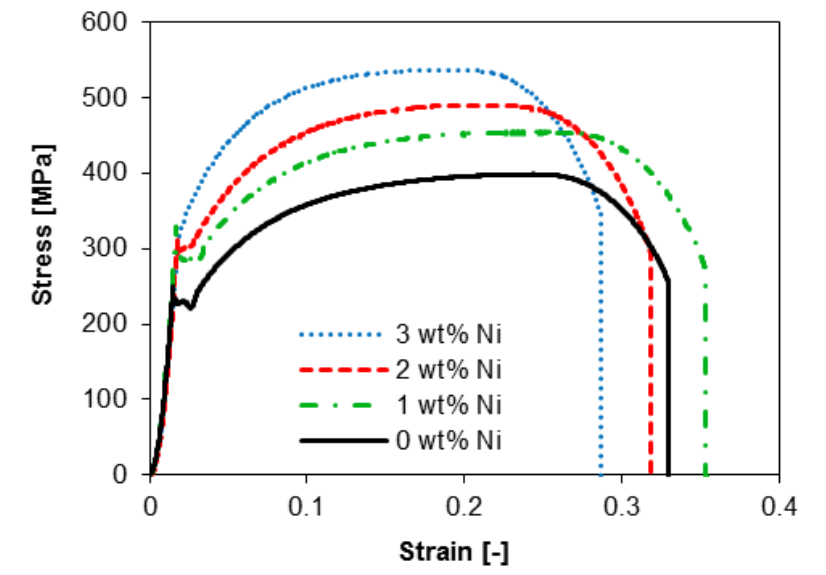

a)

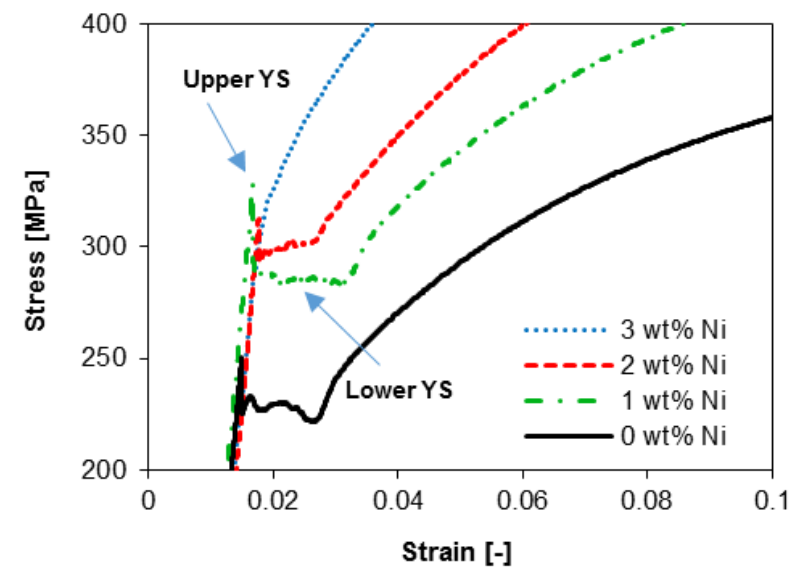

b)

Figure 6. a) SSRT results from baseline tests of LAS with Ni contents from 0 to 3 wt\% performed in air at room temperature. Strain rate of $10^{-6} s^{-1}$. b) Zoom in of the same figure showing the strain aging characteristic/Lüders bands. 


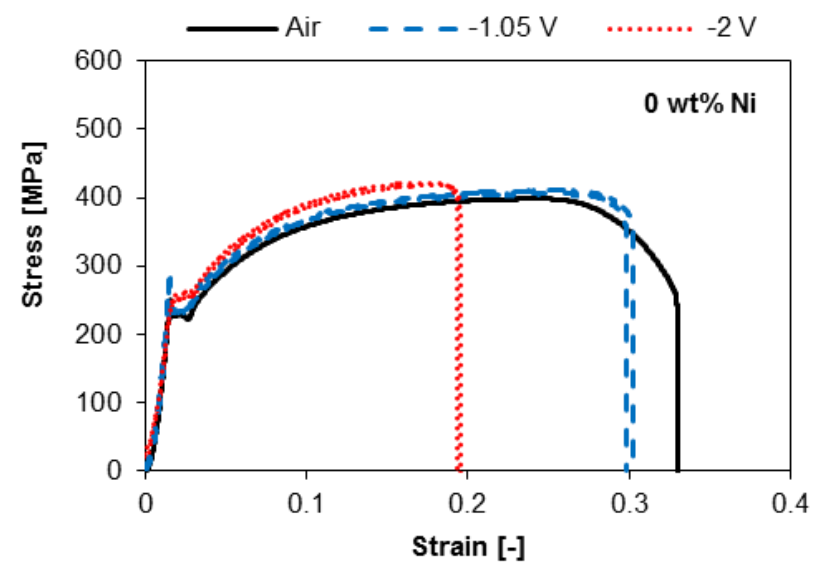

a)

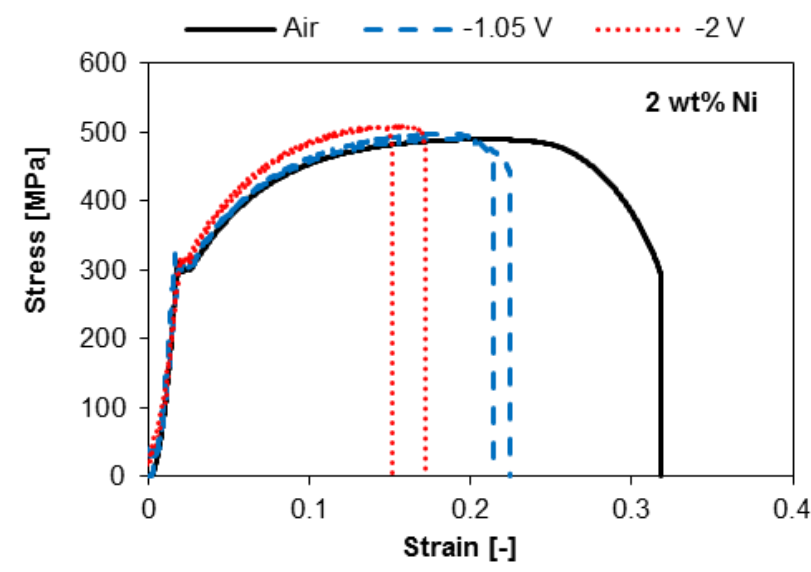

c)

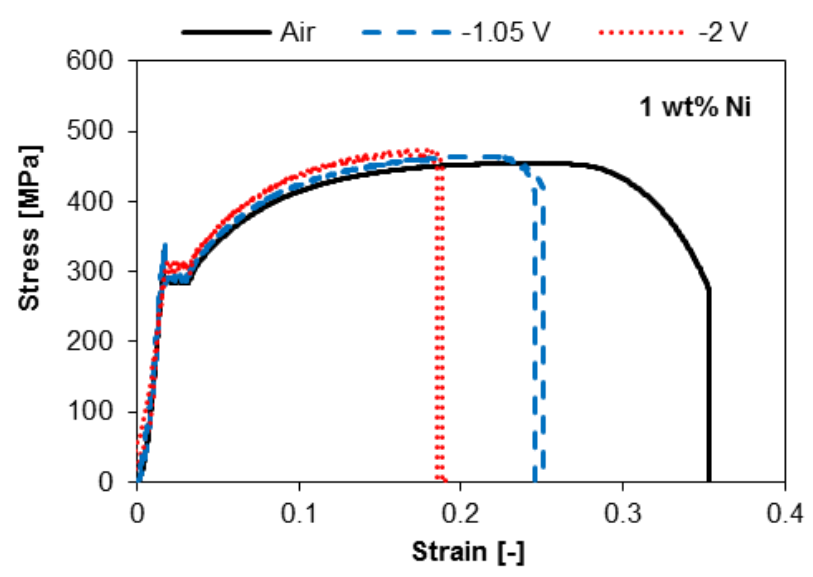

b)

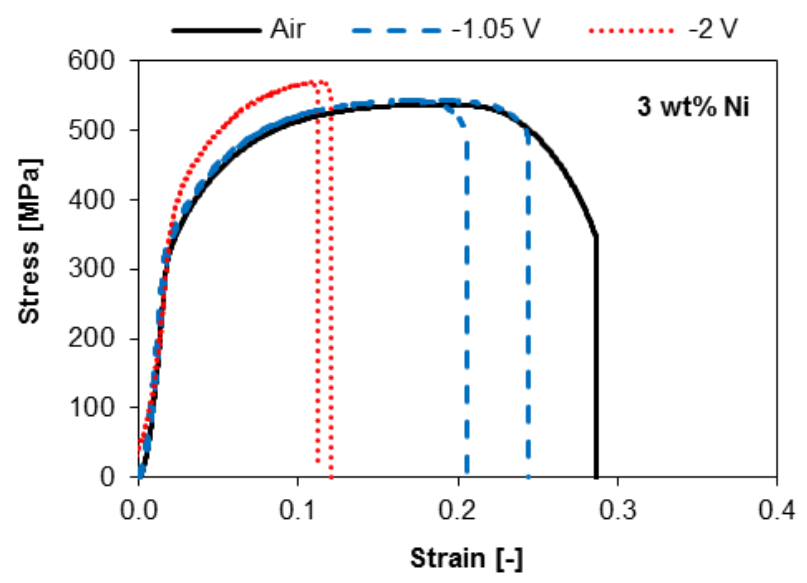

d)

Figure 7. Results from SSRT in air and at $-1.05 \mathrm{~V}_{\mathrm{Ag} / \mathrm{AgCl}}$ and $-2 \mathrm{~V}_{\mathrm{Ag} / \mathrm{AgCl}}$ in $3.5 \mathrm{wt} \% \mathrm{NaCl}$ solution at room temperature for LAS with Ni contents from 0 to 3 wt\% Ni as indicated. Strain rate of $10^{-6} \mathrm{~s}^{-1}$ in all tests.

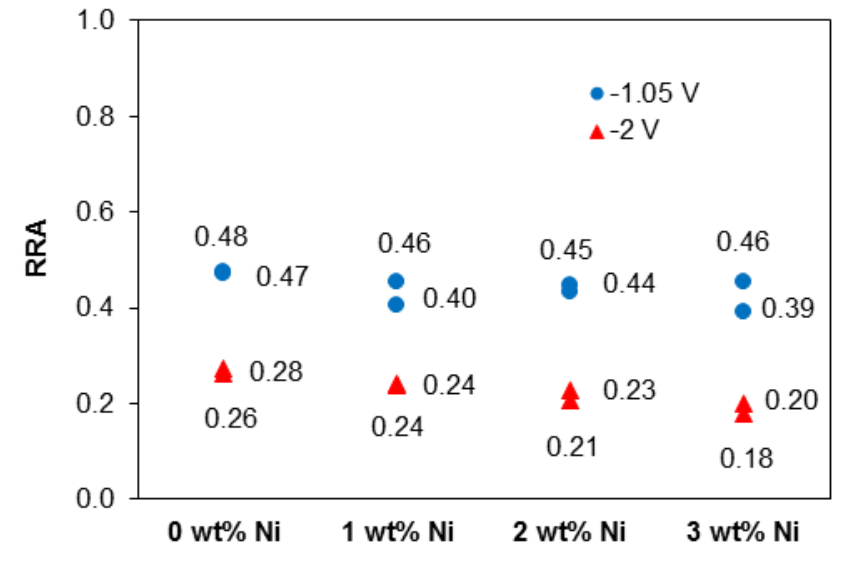

a)

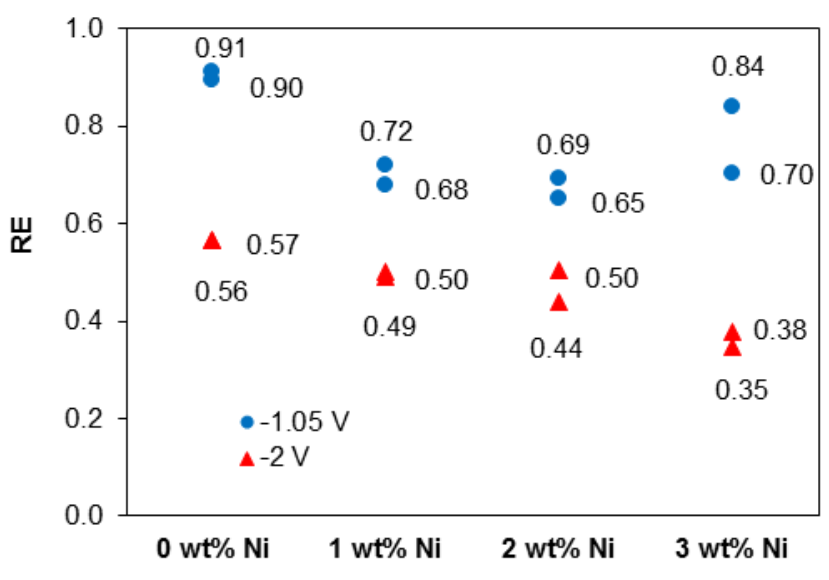

b)

Figure 8. a) Reduction in area ratios (RRA) and b) plastic elongation ratios (RE) after SSRT of LAS, with Ni contents from 0 to 3 wt\%, in air and at $1.05 \mathrm{~V}_{\mathrm{Ag} / \mathrm{AgCl}}$ and $-2 \mathrm{~V}_{\mathrm{Ag} / \mathrm{AgCl}}$ in $3.5 \mathrm{wt} \% \mathrm{NaCl}$ solution at room temperature. 


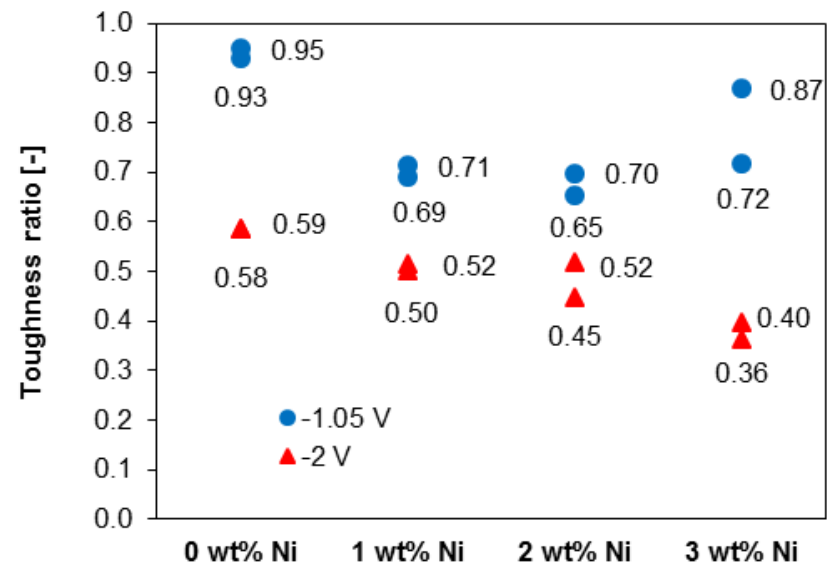

Figure 9. Toughness ratios after SSRT on LAS with Ni contents from 0 to $3 w t \%$, in air and at $-1.05 V_{\text {Ag/AgCl }}$ and -2 V $V_{A g / A g C l}$ in 3.5 wt\% $\mathrm{NaCl}$ solution at room temperature.

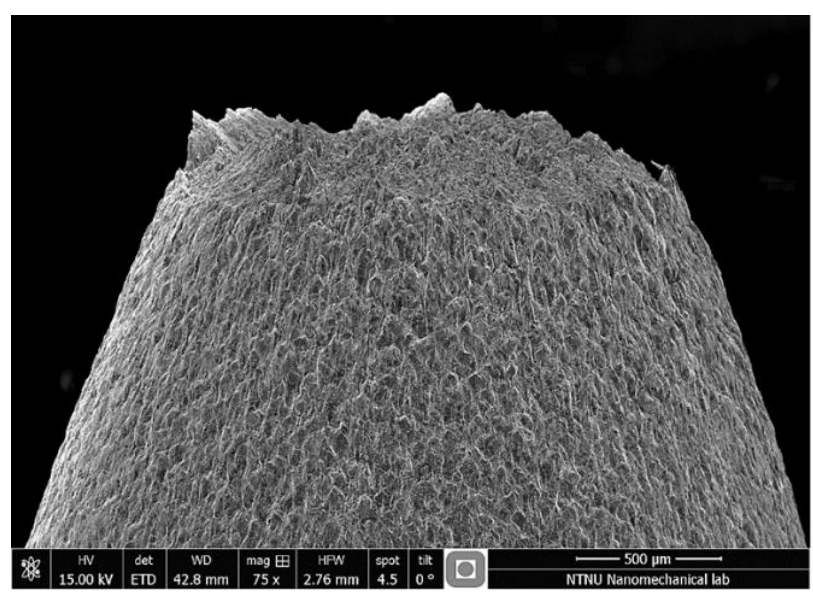

a)

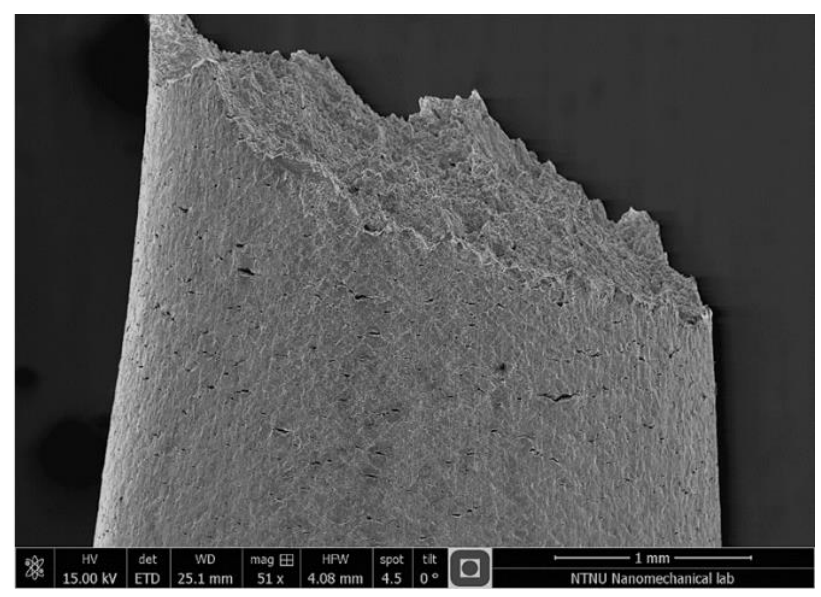

b)

Figure 10. Side view of fractured LAS samples with 1 wt\% Ni after SSRT a) in air and b) at $-1.05 \mathrm{~V}_{\text {Ag/AgCl }}$ in aerated $3.5 \mathrm{wt} \%$ NaCl solution.

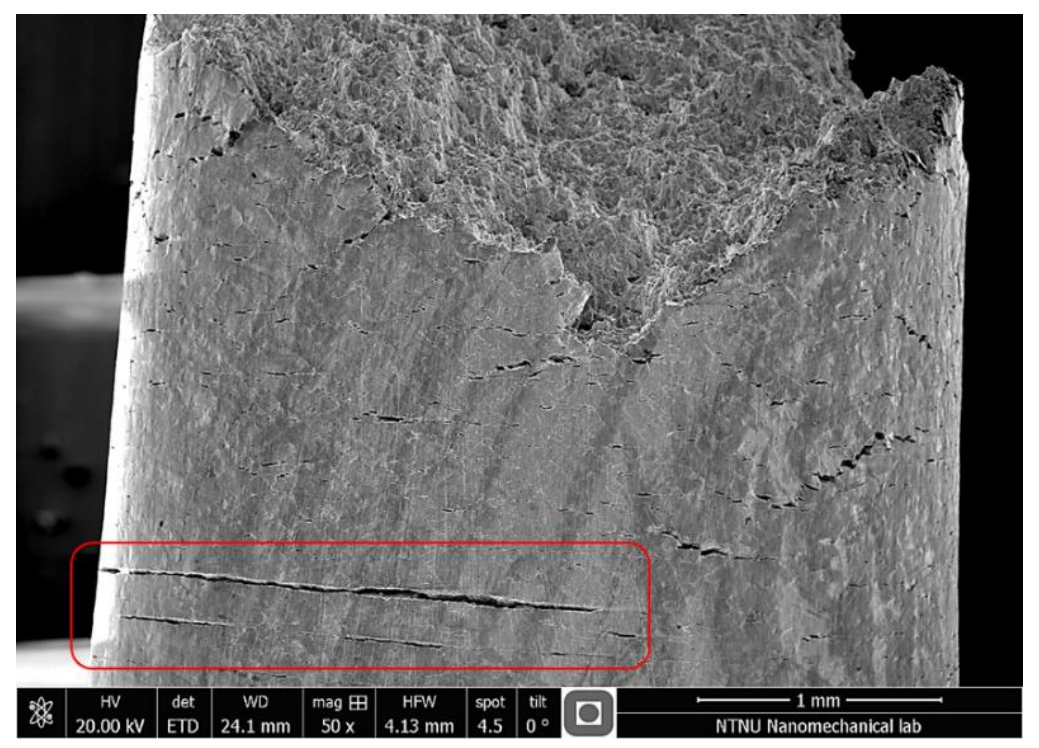

Figure 11. Secondary cracks formed, presumably, in bands of plastic deformation from machining after SSRT on a 2 wt\% Ni LAS sample tested at -2 $V_{\text {Ag/AgCl }} 3.5 w t \% ~ N a C l$ solution. 


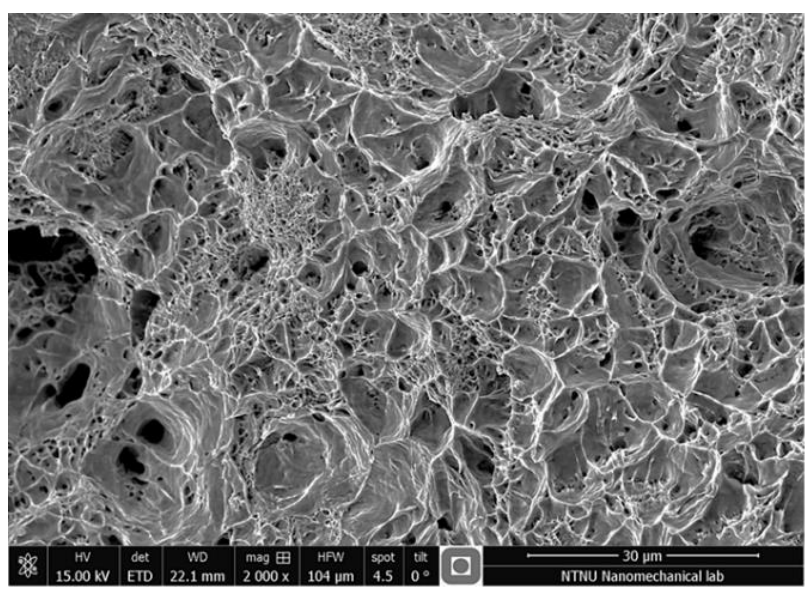

a)

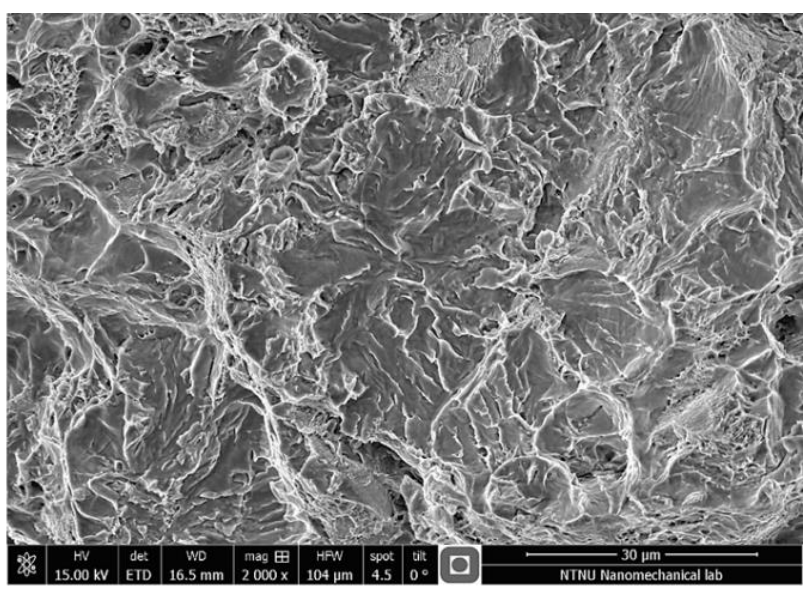

b)

Figure 12. Fracture surfaces of a $1 \mathrm{wt} \%$ Ni LAS sample after SSRT a) in air and b) at $-1.05 \mathrm{~V}_{\mathrm{Ag} / \mathrm{Agcl}}$ in aerated $3.5 \mathrm{wt} \% \mathrm{NaCl}$ solution.

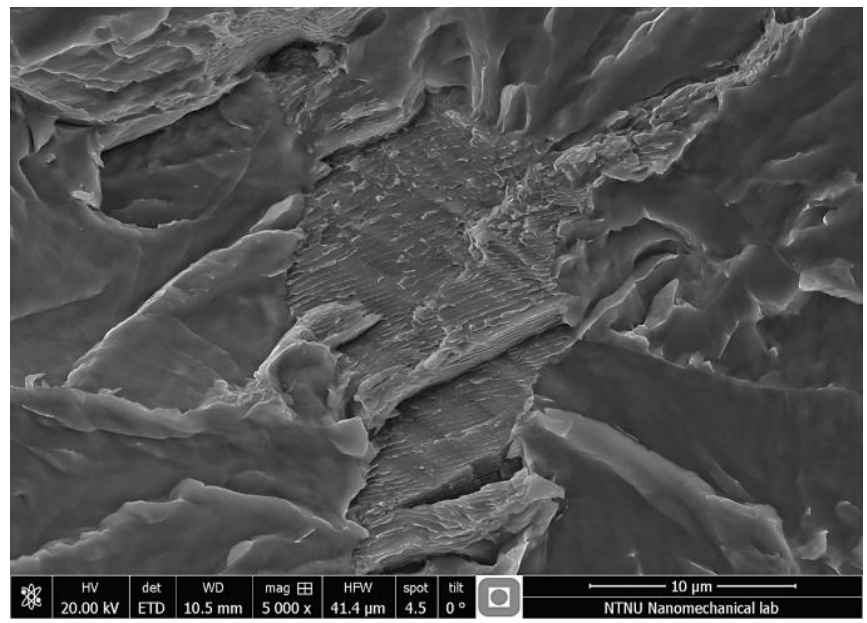

Figure 13. Fracture surface in a 0 wt\% Ni LAS sample after SSRT at -2 $V_{A g / A g C l}$ in 3.5 wt\% NaCl solution, likely the result of shear cracking across pearlite colonies.

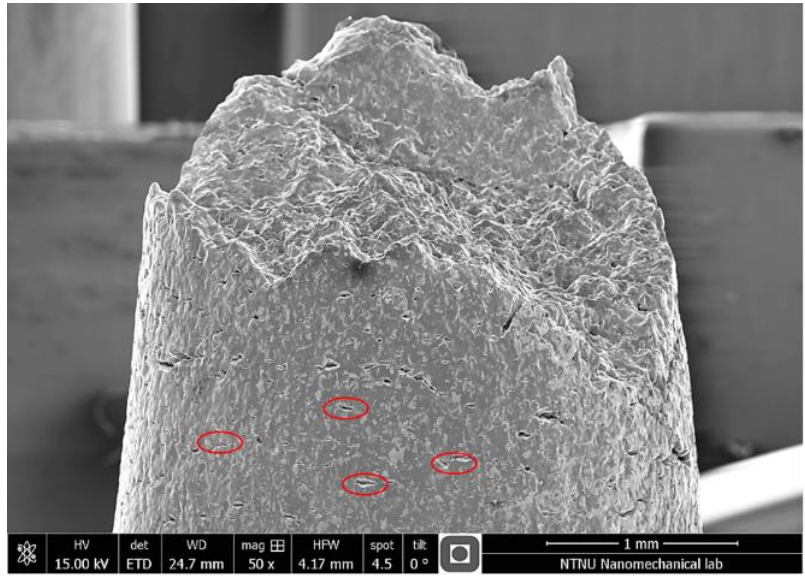

a)

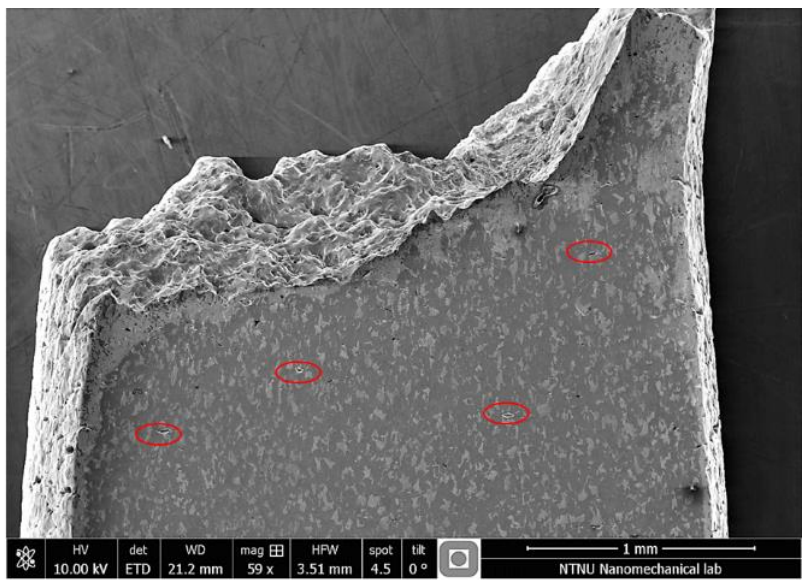

b)

Figure 14. This figure illustrates the difference in crack location for a 0 wt\% Ni LAS sample after SSRT at $-1.05 V_{A g / A g c l}$ in aerated 3.5 wt\% NaCl solution: a) surface secondary cracks and b) internal secondary cracks. In a) the fractured sample was directly electropolished to reveal the microstructure while in b) a cross section of the fractured sample was made before electropolising to reveal the microstructure. 


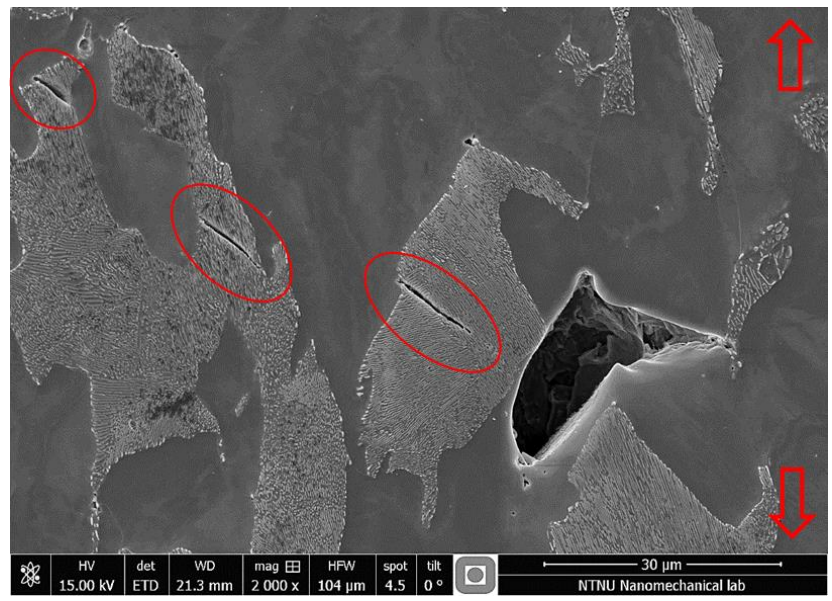

Figure 15. Internal secondary cracks in the pearlite colonies at three locations in a 0 wt\% Ni LAS sample after SSRT at -1.05 VAg/Agcl in aerated 3.5 $w t \% \mathrm{NaCl}$ solution. Arrows indicate the loading direction.

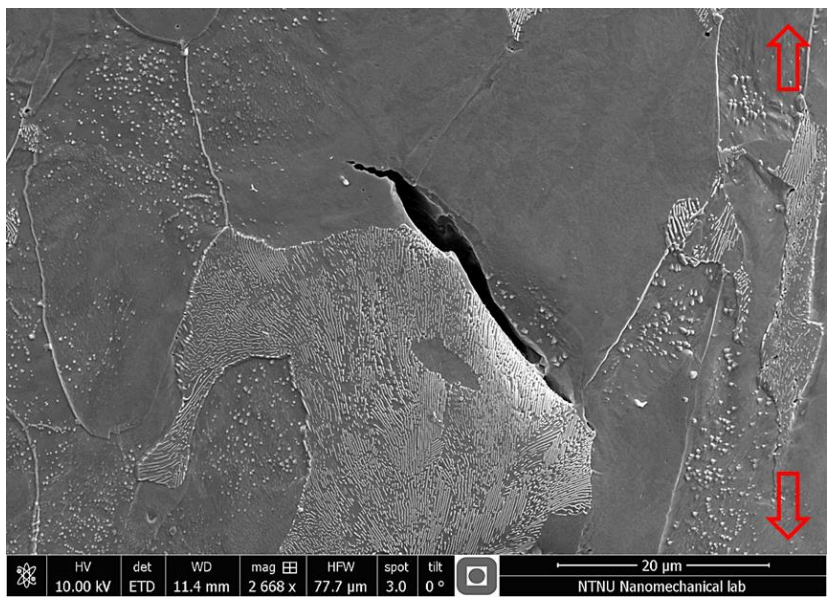

Figure 16. Internal secondary crack at the boundary between proeutectoid ferrite and pearlite in a 0 wt\% Ni LAS sample after SSRT at -1.05 $V_{\text {Ag/Agcl }}$ in aerated $3.5 \mathrm{wt} \% \mathrm{NaCl}$ solution. Arrows indicate the loading direction.

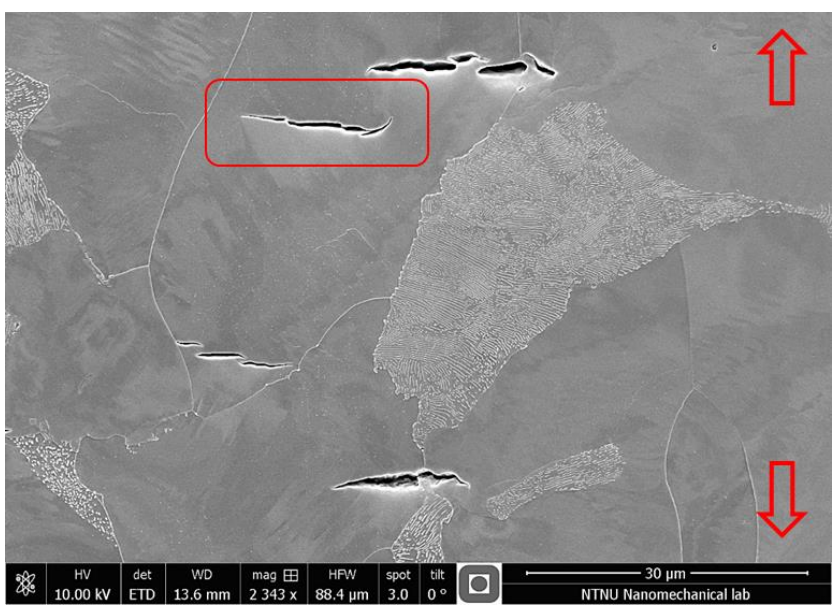

Figure 17. Surface secondary crack in the proeutectoid ferrite phase in a 0 wt\% Ni LAS sample after SSRT at -2 V V Arrows indicate the loading direction. 


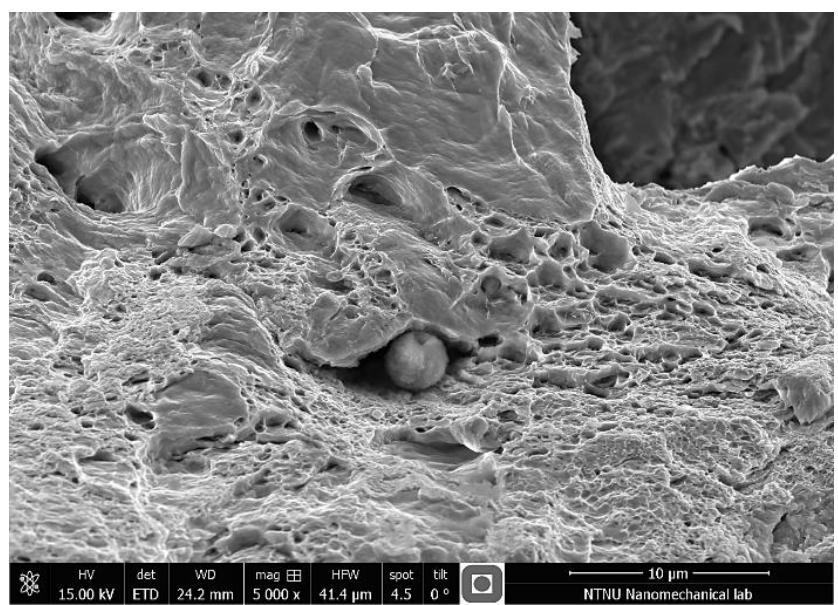

Figure 18. Particle in the fracture surface of a $0 \mathrm{wt} \%$ Ni LAS sample after SSRT at $-1.05 \mathrm{~V}$ Ag/Agcl in aerated $3.5 \mathrm{wt} \% \mathrm{NaCl}$ solution. 